
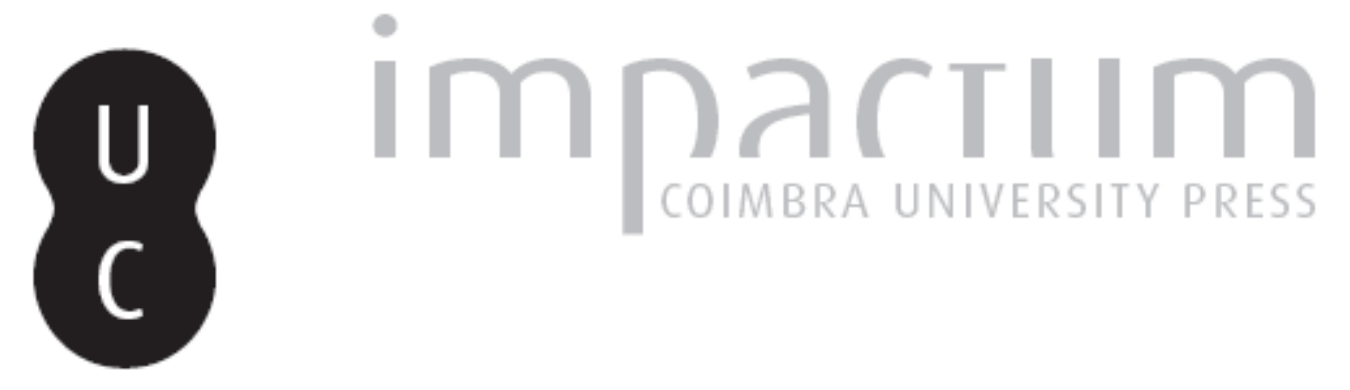

\title{
Cerâmicas finas romanas do Museu Municipal de Torres Vedras: as lucernas
}

Autor(es): $\quad$ Sepúlveda, Eurico de; Sousa, Vítor R. Cordeiro de

Publicado por: Imprensa da Universidade de Coimbra

URL persistente:

URl:http://hdl.handle.net/10316.2/45364

DOI:

DOI:https://dx.doi.org/10.14195/1647-8657_40_8

Accessed : $\quad$ 26-Apr-2023 11:26:09

A navegação consulta e descarregamento dos títulos inseridos nas Bibliotecas Digitais UC Digitalis, UC Pombalina e UC Impactum, pressupõem a aceitação plena e sem reservas dos Termos e Condições de Uso destas Bibliotecas Digitais, disponíveis em https://digitalis.uc.pt/pt-pt/termos.

Conforme exposto nos referidos Termos e Condições de Uso, o descarregamento de títulos de acesso restrito requer uma licença válida de autorização devendo o utilizador aceder ao(s) documento(s) a partir de um endereço de IP da instituição detentora da supramencionada licença.

Ao utilizador é apenas permitido o descarregamento para uso pessoal, pelo que o emprego do(s) título(s) descarregado(s) para outro fim, designadamente comercial, carece de autorização do respetivo autor ou editor da obra.

Na medida em que todas as obras da UC Digitalis se encontram protegidas pelo Código do Direito de Autor e Direitos Conexos e demais legislação aplicável, toda a cópia, parcial ou total, deste documento, nos casos em que é legalmente admitida, deverá conter ou fazer-se acompanhar por este aviso.

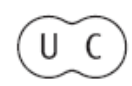


UNIVERSIDADE DE COIMBRA

FACULDADE DE LETRAS

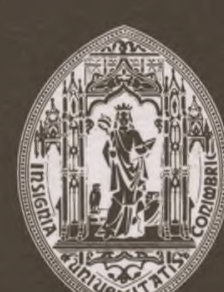

CONIMBRIGA

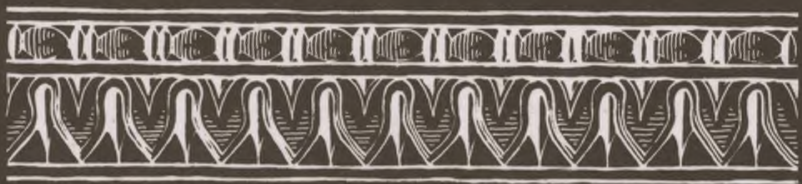

VOLUME XL - 2001 


\section{EURICO DE SEPÚLVEDA}

Economista

\section{Vítor R. CORDEIRO dE SOUSA}

Aluno do Curso de Historia (variante de Arqueologia) da F. L. L.

\section{CERÁMICAS FINAS ROMANAS DO MUSEU MUNICIPAL}

DE TORRES VEDRAS: AS LUCERNAS

"Conimbriga" XL (2001) p. 239-282

Resumo: Os autores apresentam parte do estudo que fizeram quando elaboraram o catálogo das lucernas romanas do Museu Municipal Leonel Trindade. O presente artigo dá a conhecer as lucernas em cerámica e com uma cronologia que vai desde o período republicano até aos séculos IV/V d. C.

ABStRAct: This paper is related to a study that the authors have done, when they worked on the catalogue of the Roman lamps in the Museu Municipal Leonel Trindade (Torres Vedras). Fine ware lamps were studied, within a chronology from the end of the Republican times up to IV/V centuries A. D.

Conimbriga, 40 (2001) 237-280 
(Página deixada propositadamente em branco) 


\section{CERÂMICAS FINAS ROMANAS DO MUSEU MUNICIPAL DE TORRES YEDRAS: AS LUCERNAS}

Este artigo pretende dar a conhecer o conjunto de lucernas em cerâmica, da época romana, pertença do Museu Municipal de Torres Vedras e por nós estudado durante o período em que efectuámos a sua inventariação. ${ }^{1}$ As peças, num total de 17 exemplares, encontram-se expostas na área dedicada ao período romano (dez lucernae e uma base com marca de oleiro) e guardadas nas reservas do Museu (as restantes).

Devido ao facto de estas não serem todas originárias de sítios arqueológicos do concelho, tivemos que estruturá-lo de um modo parcelar.

Em primeiro lugar, fizemos uma pequena abordagem acerca da romanização do espaço geográfico hoje pertencente a este concelho, seguindo-se o estudo dos especimens encontrados durante escavações e recolhas de superfície iniciadas na década de trinta ${ }^{2}$ em vários locais (Aldeia do Penedo, Quinta da Portucheira, Mercado Municipal de Torres Vedras e Serra de São Julião), e que irão servir de indicadores arqueológicos válidos para a presença romana nesta área, a qual ao tempo se encontrava englobada administrativamente no Município Olisiponense. ${ }^{3}$

Efectua-se também uma análise de tipo cronológico, pois a colecção é constituída por exemplares fabricados desde os finais da República até aos finais do séc. IV, inícios do séc. V d.C. As lucernas que

1 Agradecemos à Dr. ${ }^{\text {a }}$ Isabel Luna (Conservadora do Museu Municipal de Torres Vedras) todas as facilidades que nos concedeu, para estudarmos esta colecção. Incluímos ainda neste agradecimento a Cristina Pacheco, pelas sugestões quanto a formas, decorações e cores, o Carlos Anunciação, o Victor Telles, o Rui Silva e demais funcionários do Museu.

2 BELO, A. - Nótula sobre quatro lucernas de barro inéditas.

3 Ribeiro, José C. - FELICITAS IVLIA OLISIPO. Algumas considerações em torno do catálogo Lisboa Subterrânea.

Conimbriga, 40 (2001) 237-280 
têm origem alentejana, quatro no total, e que terão sido encontradas ou adquiridas por Ricardo Belo, foram estudadas tendo em conta a sua morfologia, decoração e tipologia.

Não nos foi possível, no entanto, indicar as estações arqueológicas do Alentejo a que pertenceriam, pois na lista que consta do protocolo existente entre a família Belo e a Edilidade, as peças arqueológicas são sumariamente descritas, não fornecendo qualquer tipo de informação para além da sua designação e preço.

Por sua vez, as marcas de oleiro são ordenadas por ordem alfabética e agrupadas, na medida do possível, segundo a sua origem.

Fora já deste, e como conclusão, apresentamos um pequeno resumo de ilações a que chegámos e que apenas terão valor para o conjunto de lucernas exumadas no município de Torres Yedras.

\section{CONCELHO DE TORRES VEDRAS A ROMANIZAÇÃO}

O território geográfico que actualmente se compreende como "concelho de Torres Vedras" foi, desde a pré-história aos nossos dias, alvo de uma intensa ocupação humana.

De carácter essencialmente rural, os terrenos férteis, as abundantes linhas de água, o relevo suave e clima ameno, a proximidade do estuário do Tejo (porta de entrada de povos e culturas) e a provável navegabilidade do rio Sizandro até zonas que, no nosso tempo, se encontram quase totalmente assoreadas $^{4}$, fizeram desta região um espaço preferencial para a instalação de agregados humanos.

Os testemunhos da presença dessas comunidades no passado pré e proto-histórico são abundantes. Arqueo-sitios como Bonabal, a tholos do Barro, necrópole do Cabeço da Arruda, Castro da Fórnea, Castro do Zambujal, Gruta da Cova da Moura e Ermegeira, entre outros, são a prova mais do que evidente da importância desta zona nas épocas supracitadas.

Pouco se sabe, todavia, sobre as populações pré-romanas desta região. Através de Estrabão ${ }^{5}$ supõe-se que os Túrdulos, no séc. III a.C.,

4 Hoffmann, Gerd; Shulz, Horst D. - Cambio de situación de la linea costera y estratigrafía del holoceno en el valle del Sizandro/Portugal.

${ }_{5}^{5}$ Cit. por MANTAS, Vasco - Inscrições do Museu Municipal de Torres Vedras, p. 8.

Conimbriga, 40 (2001) 237-280 
provenientes da Bética, provavelmente da bacía do Guadalquivir, tenham ocupado os povoados existentes na faixa litoral entre o Tejo e o Mondego. Correspondendo este dado à realidade, a região de Torres Vedras não teria sido excepção.

No séc. II a.C., Décimo Junio Bruto terá chegado a Olisipo (C. 138-137 a.C.), onde se estabeleceu e fortificou o povoado preexistente, que serviu, posteriormente, como uma das bases das campanhas contra os Lusitanos e os Galaicos.

É com esta cronologia aproximada que encontramos os vestígios romanos mais antigos do concelho: denários de prata nas proximidades do Casal de Sto. António ${ }^{6}$, de Torres Vedras ${ }^{7}$ e da Serra de S. Julião. ${ }^{8}$

Do séc. I a.C. também encontramos denários na Serra de S. Julião9, em Torres Vedras - zona do mercado ${ }^{10}$ 11, próximo do Figueiredo bem como um fragmento de lucerna com aleta, proveniente da Quinta da Portucheira, que ora publicamos. Estes numismas e o fragmento de lucerna são, até ao momento, os indicadores de uma cronologia republicana para esta região. O restante espólio romano encontrado no concelho que se encontra no Museu Municipal aponta para cronologias mais recentes. ${ }^{\mathbf{1 2}}$

Observando o mapa da distribuição dos achados romanos no concelho, verificamos uma intensa ocupação, através dos muitos sítios onde a romanização está bem representada: Ferrarias, Penedo, Quinta da Macheia, Quinta da Portucheira, Quinta de S. Gião, Serra de S. Julião, Sevilheira e Torres Vedras (Mercado Municipal, Castelo e Cemitério de S. João), entre outros locais que até ao momento possuem vestígios mais escassos.

6 BeLo, Aurélio R. - Nótulas sobre a arqueologia de Torres Vedras e seu termo. XXXII. (Cunhado por Publio Cornelius Sula em 151 a. C.).

7 BELO, Aurélio R. - Nótulas sobre a arqueologia de Torres Vedras e seu termo. XIV. (Cunhado por C. Serveilius em 136 a. C.).

8 BELO, Aurélio R. - Nótulas sobre a arqueologia de Torres Vedras e seu termo. VII. (Cunhagem da família Vargunteia em 138 a. C.).

9 BELO, cit. 8. (Cunhada por C. Licinius Macer, em 84/83 a. C.).

10 Belo, cit. 7. (Cunhagem de Q. Antonius Balbus, cônsul em 82 a. C.).

11 BeLo, Aurélio R. - Nótulas sobre a arqueologia de Torres Vedras e seu termo. XXXV. (Cunhada por M.(?) Nonius Sufenas, comemorando Sex. Nonius Sufenas, em 57 a.C.).

12 Trindade, Leonel; Ferreira O. da V. - Objectos lusitano-romanos do Museu de Torres Vedras.

Conimbriga, 40 (2001) 237-280 
Esta ocupação deve ter sido dirigida para a exploração agrícola, devido às características do clima e dos solos desta região, com fortes probabilidades no campo das produções oleícola e vinícola. Daqui resultaria uma profusão de villae (Aldeia do Penedo - villa rústica dos Celtios (?), Quinta da Macheia, Serra de S. Julião e Quinta de S. Gião) e de pequenos casais que, pela sua proximidade, não devem ter adquirido as dimensões de latifundia. Os produtos resultantes desta actividade beneficiariam da proximidade do mercado olisiponense (e escalabitano), para o qual seriam dirigidos, quer por via terrestre ${ }^{13}$, quer, possivelmente, por via marítima. ${ }^{14} 15$

Um dado importante em relação à actividade oleícola-vinícola reside num pedestal funerário monumental epigrafado (Museu Municipal de Torres Vedras), encontrado na Quinta da Macheia e atribuível à primeira metade do séc. I d.C., com vestígios de reutilização como peso de prensa de lagar, provavelmente ainda durante a época romana.

Alguns proprietários dessas villae deveriam pertencer a uma certa "burguesia urbana", possuiriam em Olisipo cargos políticos e estariam inscritos na ordo decurionum, o que vem, mais uma vez, demonstrar a dependência desta região em relação a essa cidade.

Não se conhecem, até ao momento, provas arqueológicas ou epigráficas da existência de uma localidade com as dimensões e importância de um vicus. A existir, poderíamos supô-lo entre o monte do Castelo de Torres Vedras e a zona do Mercado Municipal e/ou do Cemitério de S. João.

Em relação à rede viária, a área de Torres Vedras estaria servida por uma via secundária que faria a ligação entre Olisipo e Aeminium, passando por Loures (miliário encontrado a sul), Dois Portos (da qual partiria um ramal de ligação a ler abriga, próximo de Alenquer, a fím de atingir a via principal, que ligava Olisipo a Bracara Augusta), Eburobrittium, Collipo e Conimbriga ${ }^{25}$

Haveria possivelmente também um sistema de caminhos secundários que, acompanhando a orla costeira, ligaria esta zona à região de Sintra e Olisipo.

13 MANTAS, cit. 5, p. 77.

14 Desconhece-se, para o período romano, a navegabilidade do rio Sizandro.

15 AlarCão, J. - O domínio romano em Portugal, 1988, p. 97.

MANTAS, V. - Comércio marítimo e sociedade nos portos romanos do Tejo e do Sado, 1996, p.399, fig. 1.

Conimbriga, 40 (2001) 237-280 
No campo da epigrafia, o municipio de Torres Vedras é um dos mais ricos da Lusitânia. O levantamento e interpretação das epígrafes romanas do concelho (existentes ou não no Museu Municipal), efectuado por Vasco Mantas ${ }^{\mathbf{1 6}}$ continua a ser urna das melhores abordagens para podernos ter uma imagem aproximada da sociedade romana, para o período cronologicamente compreendido entre os inicios do séc. I d.C. e os finais do séc. II d.C. Também J. Cardim Ribeiro inclui, nos seus estudos sobre o contexto social, político, religioso, económico e viário do município olisiponense, referências a esta região. ${ }^{17}$

Verifica-se, assim, a existência de uma sociedade essencialmente de indígenas fortemente romanizados e, simultaneamente, conservadores dos costumes ancestrais, com uma adesão ao modus vivendi romano efectuado de um modo rápido. Como exemplo, podemos citar a permanência da antroponímia indígena a par com a adopção de nomes latinos. Este fenómeno verifica-se em muitas das epígrafes com a existência dos tria nomina e com sobrevivência dos nomes autóctones como cognomen. ${ }^{18} 19$.

Administrativamente, a região tómense pertencia ao Município Olisiponense situando-se possivelmente na sua "fronteira" norte, como parecem demonstrar as epígrafes do concelho com referências à tribo Galéria, e estava englobada, por sua vez, no território mais vasto do Conventus Scallabitanus.

\section{LUCERNAS TARDO-REPUBLICANAS}

Do cemitério romano da Quinta da Portucheira provém um fragmento de lucerna com o perfil completo do infundibulum (n. ${ }^{\circ}$ 1) que se insere no tipo Dressel-Lamboglia 2.111 É a única lucerna com uma cronologia compreendida entre o séc. II a. C. e o câmbio da Era do acervo do Museu.

16 Mantas, cit 5.

MANTAS, Vasco - Três inscrições romanas do concelho de Torres Vedras.

17 RibeiRo, J. Cardim - Estudos histórico-epigráficos em torno da figura de $L$. Ivlivs Maelo Cavdicvs.

RIBEIRO, cit. 3.

18 MANTAS, cit. 5, p. 31.

19RIccI, Marina - Per una cronologia delle lucerne tardo-republicana.

Conimbriga, 40 (2001) 237-280 
Trata-se de um produto das olarias centro-itálicas que dirigiram os seus excedentes de produção para os mercados da Hispania e Norte de Africa (Marrocos). As lucernas produzidas nestas oficinas caracterizam-se por possuírem uma pasta bem depurada, de tons beiges, com "verniz" de cor vermelha, brilhante e de boa qualidade, semelhante ao Glanztonfilm das sigillatas itálicas, o que não impede que, por vezes, apareçam outros tipos de pasta e "verniz" (cinzenta e negro, respectivamente). Com corpo troncocónico, possuem bico em forma de cauda de andorinha, aleta lateral colocada à direita do depósito, asa em fita e pé anelar, com uma base que pode ser côncava ou plana. A decoração do disco é efectuada por uma ou várias molduras circulares e, em regra geral, por pequenas pérolas, que também podem decorar as paredes laterais do infundibulum, o que não obsta a existência de outros tipos decorativos. As aletas, por sua vez, apresentam linhas incisas e círculos impressos na extremidade.

Como já afirmámos, esta produção tem uma diacronia vasta, tendo como limites os achados de Akrai (Siracusa), que atingem a segunda metade do séc. III a.C.20, e os de Albintimilium, que aparecem em estratos datados do primeiro decénio do séc. I d.C. ${ }^{21}$, o que nos vai permitir arriscar para o exemplar da Quinta da Portucheira, recolhido em prospecções de superfície, cronologia que aponta para toda a segunda metade do séc. I a.C. Por outro lado, se atendermos aos numerosos numismas encontrados na zona de Torres Vedras (denários republicanos), e à influência de Olisipo, cidade com estatuto de Oppidum Civium Romanorum desde meados do séc. I a.C.22, parece-nos não ser aberrante a cronologia que propomos. ${ }^{23}$ Sendo uma das formas de lucerna mais utilizadas durante o período cronológico que apontámos, possui, uma vasta difusão ${ }^{24}$, a qual se estende desde a Hispânia (Portu-

20 ARXÉ i GALVEZ, Joaquim - Les llanties tardo-republicanes d'Empuries.

${ }^{21}$ RICCI, cit. 19, p. 185-187.

Atípico, a este intervalo cronológico, existe um exemplar, de Óstia, exumado em estratos de idade flávia.

22 RiBEIRO, cit. 3, p. 76-78.

23 Agradecemos ao Prof. Vasco Mantas as sugestões que nos deu quanto à cronologia que indicámos.

24 RICCI, cit. 19, p. 185-187.

ARXÉ i GALVEZ, cit. 20, p. 24-26 e notas referentes à difusão desta forma em Espanha.

AMARÉ, Ma. T. - Lucernas romanas en Aragon. 
gal - Alcáçova de Santarém ${ }^{25}$, Cabeço de Vaiamonte ${ }^{26}$, Conimbriga ${ }^{27}$, Lomba do Canho e Mértola28; Espanha - Alcudia de Elche, Ampúrias, Arcobriga, Bilbilis, Cabezo Agudo, Celsa, Coto Fortuna e Mina Virgen de las Huertas - Mazarrón, Molinete, Pollentia, Segobriga ${ }^{29}$,Selilha, Tossal Gort, Valdeherrera), à Ligúria (Albingaunum - Albenga, Albintimilium), Itália Central (Alba Fucens, Graviscae - Tarquinia ${ }^{30}$, Luni, Ostia, Roma - Casa de Lívia, Fórum de César, Teatro de Pompeu); e ao Norte de África (Cartago, Portus Magnus - Oran, Tamuda, Thamusida); França (Cavaillon), e diversos naufrágios ocorridos ao longo do séc. I a.C. (Cap Dramont A, Madrague de Giens, Plantier 3); para além de exemplares pertencentes a espólios de museus europeus (Belas Artes da Hungria, British Museum, Zentralmuseum de Mainz).

Atendendo à decoração da aleta, com círculo e três incisões, e ao "verniz" (de cor) vermelho acastanhado brilhante, pensamos poder indicar como paralelos para este fragmento, apesar de não se possuírem as formas da asa, bico e disco, as lucernas que foram exumadas nas escavações da cidade de Ampúrias e depositadas no seu Museu Municipal, com os números de inventário 11008,11012, 11113 e 11122 (respectivamente da Reserva Gandia, Angulo SW do Fórum e origem desconhecida), de Alcudia de Elche ${ }^{31}$, Coto Fortuna de Mazarrón ${ }^{32}$ (Museu Arqueológico Municipal de Murcia, sem número de inventário) e a do Museu Arqueológico Provincial de Girona (n. ${ }^{\circ}$ de inventário 1124). ${ }^{33}$

25 Diogo, A. M. D. - O material romano da primeira campanha de escavações na Alcáçova de Santarém.

26 Nunes, J.; Guerra, A.; FABIÃo, C. - As lucernas do acampamento militar da Lomba do Canho - Arganil.

${ }^{27}$ AlarCão, A.; PONTE, S. - Lucernas.

Dos exemplares de Conimbriga, num total de quatro, apenas um $\left(n .{ }^{\circ} 1\right)$ foi encontrado num pavimento pré-augustano, enquanto que os restantes foram exumados em entulhos ligados a várias reestruturações.

28 ALMEIDA, J, A. - Introdução ao estudo das lucernas romanas em Portugal.

29 ABAsCal Palazón, J. - Lucernas romanas de Segóbriga.

30 Hanoune, R. - Lampes de Graviscae, p. 240, pl. 3, n. ${ }^{\circ} 4,6$.

31 ARXÉ i GalveZ, cit. 20.

32 Ramos Folques, A.; Ramos Fernandes, R. - Excavaciones en la Alcudia de Elche durante los años 1968-1973.

33 Amante SÁNCheZ, M. - Lucernas romanas de la región de Murcia - Hispania Citerior.

Conimbriga, 40 (2001) 237-280 
Estas sete lucernas delfiniformes ${ }^{34}$ apresentam as aletas decoradas com incisões ou incisões e círculo, pelo que serão produtos de uma mesma oficina itálica.

\section{LUCERNAS DE ÉPOCA IMPERIAL Início da 2a metade do séc. I d.C. primeira metade do séc. II d.C.}

As lucernas n. ${ }^{\text {os }} 2$ e $3{ }^{35}$ e a asa $n .^{\circ} 4$ pertencentes ao espólio do Museu e provenientes de diversos estabelecimentos de ocupação romana - Mercado Municipal, Aldeia do Penedo e Serra de S. Julião, respectivamente - constituem o grupo de lucernae alto-imperiais (Dressel-Lamboglia 20) produzidas na Itália Central durante o intervalo de tempo balizado pelo início da dinastia dos Flávios e o período dos imperadores hispânicos. ${ }^{36}$ Produções regionais e locais poderão ter, no entanto, uma diacronia mais vasta, ou seja de todo o séc. II e princípios do séc. III d.C. E o caso dos exemplares pertencentes ao espólio do Porto Circular de Cartago, de origem tunisina e marroquina. ${ }^{37}$

A decoração do disco da lucerna n. $^{\circ} 2$ é formada por uma cena de venatio entre animais, em que um cão persegue um javali, atacando-o. Esta desenvolve-se em sentido sinistrógiro e poderá representar, também, um episódio de caça.

Este tipo de representação goza de uma grande popularidade entre o repertório decorativo dos oleiros desta época, motivo pelo qual o vamos encontrar a decorar vasos de terra sigillata galo-romana e hispânica. Em taças de vidro tardias, esta decoração é mais elaborada, podendo-se ver, por exemplo, um caçador munido de lança enfrentando um javali que é encaminhado para ele por dois cães. Apenas conseguimos obter um único paralelo perfeito para este motivo decorativo. Trata-se de uma lucerna inteira, pertencente à Olaria do Pinheiro,

34 Se traçarmos uma linha longitudinal, obtêm-se perfis que fazem lembrar a forma de golfinho.

35 BELO, cit. 7.

TRINDADE; FERREIRA, cit. 12, p. 266, Est. III. 5.

36 Ponsich, refere-se a uma lucerna de Tipasa com cronologia do principado de Vespasiano.

37 KNOWLES, K - Excavations at Carthage, p. 32-35. 
Alcácer do Sal, de meados/segunda metade do séc. III d.C., escavada por Françoise Mayet e Carlos Tavares da Silva, e que estes investigadores pensam ter sido produzida localmente, através da técnica da remoldagem, a partir de urna lucerna de importação do tipo DresselLamboglia 2738 Para além deste exemplar, poderemos apontar como paralelos os de Vindonissa ${ }^{39}$, British Museum $^{40}$, Belo e muito remotamente, os de Conímbriga ${ }^{41}$, em que esta cena se desenrola, na generalidade, para a direita. As representações de javalis correndo para a esquerda ou para a direita são vulgares CBalsa, Cacela, Calagurris, Conímbriga, Cotta, Faro, Tanger, Sala, Volubilis,...), aparecendo em grande quantidade no espólio da Necrópole dos Oficiais em Cartago. Esta lucerna apresenta na base urna marca em forma de palma.

Quanto ao fragmento de lucerna com o . $^{\circ} 3$, tivemos dificuldade em classificá-lo, atendendo ao facto de não possuirmos o seu fundo, disco e bico. No entanto, pensamos poder inclui-lo nesta série, partindo dos paralelos que estabelecemos com as lucernas de Santa Bárbara, Lu 366,406 (?) e $505^{42}$ e com um fragmento de Tróia de Setúbal (n. ${ }^{\circ}$ 76), que apresenta a mesma "orla arredondada e lisa" e "disco cóncavo".43 É de salientar o facto de nos exemplos acima indicados todas as lucernas estarem munidas de urna asa de perfil triangular, perfurada, tipo Ponsich 8, enquanto que o exemplar da aldeia do Penedo tem uma asa mais circular. Por fim, parece-nos que o disco desta lucerna terá

38 MAYet, F.; Silva, C. T. - L'atelier d'amphores de Pinheiro (Portugal), p. 141, 162, fig. 67. 135 .

Agradecemos ao Dr. C. Tavares da Silva ter-nos facultado a monografía que citamos.

No que concerne à terra sigillata e ao vidro, consulte-se:

Hermet, F. - La Graufesenque, p. 109-113, Pl. 67 (2-5) “chien-sanglier".

MAYET, F. - Les céramiques sigillées hispaniques. II, Pl. 2546, 2548.

HARDEN, D. - The Wint Hill hunting bowl and related glasses, p. 60, fig. 16, 17.

39 LOESCHCKE, S. - Vindonissa, tafel XIII, n. ${ }^{\circ}$ S 269-272, 273, 503.

Estes exemplares apresentam reproduções de cenas de caça entre "Eber und Hund".

40 Balley, D. - A catalogue of the lamps in the British Museum, p. 74,158, 168, Plate 14 Q897.

${ }_{41}$ Belchior, C. - Lucernas romanas de Conimbriga, p. 44, Est. VII.10, 11.

A autora propõe estarmos perante o salto de ataque de um cão em relação a uma presa, hipoteticamente um javali.

42 MaIA, Maria; MaIA, Manuel - Lucernas de Santa Bárbara, p. 107, 114, 123.

${ }_{43}$ Costa, M. E. - Lucernas romanas de Tróia de Setúbal, p. 135. 
sido decorado, pois conseguimos distinguir no quarto superior direito, junto à orla, um pequeno relevo, que pensamos ser o que resta dessa decoração.

Quanto à asa com o n. ${ }^{\circ}$, pouco poderemos acrescentar, para além de se tratar de uma asa característica do terceiro quartel do séc. I d.C. e de todo o séc. II d.C., a qual se ajusta a qualquer tipo de lucerna em voga durante este período.

\section{Século III d.C. / inícios do séc. IV d.C.}

A lucerna n. ${ }^{\circ}$, proveniente da Quinta da Portucheira, é do tipo Dressel-Lamboglia 28 A, na sua variante mais tardia, com uma cronologia dos princípios do séc. III d.C. Munida de bico redondo a tender para o cordiforme, possui orla larga, decorada com pérolas e tem o disco liso. A asa é do tipo circular perfurada, com decoração de espiga com mais de dez folhas.

Ao lugar do Penedo pertence a lucerna $\mathrm{n} .{ }^{\circ} \mathbf{6}$, que se insere no grupo característico do séc. III d.C. - tipo Dressel-Lamboglia 30 A. Este exemplar encontra-se reconstituído com resina, o que dificultou o seu estudo, podendo mesmo haver a possibilidade da asa não pertencer ao restante conjunto. O disco, por sua vez, encontra-se bastante prejudicado pelas colagens e enchimentos, o que obsta a uma interpretação total da decoração. ${ }^{44}$ Morfologicamente segue a forma-tipo, com uma orla bem marcada e decorada, assim como o disco, que é ligeiramente côncavo, com bico grande e cordiforme. Considerando a asa como pertencente a esta lucerna, ela é perfurada e preenchida, centralmente, por incisões do tipo "unhada", dispostas em forma de palma. A base é ligeiramente côncava, não se encontrando limitada por qualquer anel. Procurámos paralelos, quer para a decoração da orla, quer para a do disco, chegando à conclusão de que poderá haver uma certa ligação, não exclusiva, entre as orlas com estrias radiais e os temas mitológicos. Parece ser o caso das lucernas de Balsa - Artémis; da Barrosinha Mercúrio; de Cartago - Bacchus e Diana; de Conimhriga - Luna e Sol; de Tamudá - Diana; e de Tavira - Mercúrio. Em relação ao busto que decora o disco, discordamos da hipótese proposta por Ricardo Belo de se tratar do deus Mitra.

${ }^{44}$ BeLo, cit. 2, p. 98-102.

Conimbriga, 40 (2001) 237-280 
Já em 1960, Nunes Ribeiro, quando estudou as lucernas do depósito votivo de Peroguarda, pôs em dúvida esta associação numa nota que escreveu sobre o artigo de Belo. ${ }^{45}$ De facto, não conseguimos encontrar representações, de origem grega ou romana, em que Mitra não deixe de usar o "barrete frigio", um dos símbolos pelo qual se distingue, iconográficamente, de Hélios. ${ }^{46}$ Embora se encontrem, por vezes, representações em que os traços fisionómicos e o tipo de penteado, apartado ao meio, em ondas, e caindo em cascata pelos ombros, sejam idênticos, a ausência do referido barrete e da coroa radiada parecem ser razões suficientes para excluir o paralelismo com Mitra 47 Tentámos encontrar um paralelo para ela, partindo do pressuposto de que a figura no disco da lucerna do Penedo é Hélios (Sol).

Embora o tema "deus Sol" seja extremamente popular na temática referente ás lucernas (Aldeia de Santa Margarida, Conímbriga, Peroguarda, Quintos, Santa Bárbara, Tróia,... $)^{48}$, apenas no recente trabalho de Maria e Manuel Maia encontrámos uma sistematização na qual poderemos enquadrar a nossa figura. Pertencerá, assim, ao punção tipo $b$ que se caracteriza por ter sete raios, cabelos sobre os ombros, túnica presa nos ombros por fíbulas circulares e com decote. ${ }^{49}$ No entanto, pensamos ter um paralelo quase perfeito se a compararmos com a representação que figura sobre o disco da lucerna de Quintos - Beja ${ }^{50}$, embora esta não possua, como a nossa, o campo inferior (espaço compreendido entre a parte final do busto e a orla) preenchido por pequenas pérolas, que deveriam ter um efeito meramente decorativo. ${ }^{51}$

45 Ribeiro, F. N. - Lucernas romanas de Peroguarda, p. 21, nota 57.

46 Cumont, Franz - Mithra e Sol, p. 1373-1386.

47 Becatı, G. - I Mitrei - Scavi di Ostia, vol. Secondo.

48 Elisabeth Cabral apresenta, dentre as peças de Tróia, uma lucerna do tipo Dressel-Lamboglia 20 (n. ${ }^{\circ}$ 105), com figura radiada, que classificou como Mitra, atendendo ao facto de existir, para além da coroa de raios, um chicote noutro local do disco, que a autora considerou como atributo daquele deus.

Para uma informação mais pormenorizada em relação a este tema,veja-se:

AmARÉ, M. T. - Lucernas romanas de La Rioja, p. 45.

49 MAIA, cit. 42 , p. $51,53,54$.

Como não possuímos a metade direita do disco, podemos reconstituir a figura, com pelo menos, sete raios, o que seria, esteticamente, mais correcto. Em relação às fíbulas, identificamos apenas a do ombro direito.

50 LOPES, M. C. - Lucernas, p. 83, fig. 24.4.

51 Amaré Tafalla, quando amavelmente nos respondeu sobre esta dúvida, interpretou do mesmo modo o significado destas pérolas.

Conimbriga, 40 (2001) 237-280 
Para além da lucerna que acabámos de estudar, existem mais duas, pertencentes à forma Dressel-Lamboglia $30 \mathrm{~B}$, também do séc. III d.C., uma proveniente da Aldeia do Penedo n. ${ }^{\circ}$ 7, e outra da Quinta da Portucheira n. ${ }^{\circ}$ 8.52 Produções menos cuidadas têm uma cronologia mais longa perdurando até aos inícios da centúria seguinte, altura em que são substituídas pelas lucernas paleocristãs, produzidas em terra sigillata africana clara.

Estes exemplares possuem em comum uma orla larga, decorada com pérolas dispostas em círculo (variando o número em função do seu tamanho e da largura da orla), orifício de alimentação centrado e disco sem decoração.

Considerámos a n. ${ }^{\circ} 7$ munida de uma asa compacta, com perfil de tronco de pirâmide, que indica ter sido produzida em pleno floruit desta forma, ou seja, durante toda a segunda metade do séc. III d.C.53 Por sua vez, e atendendo ao facto de a lucema n. 8 se encontrar reduzida a cerca de metade na qual estaria incluída a asa $^{54}$, atribuímos-lhe a cronologia geral para este tipo. Esta forma foi profusamente difundida e é um elemento omnipresente em sítios arqueológicos com ocupação romana deste período (cidades, villae, estabelecimentos industriais e necrópoles).

Para Portugal, e apenas como mero sentido exemplificativo, iremos encontrá-la nos espólios referentes a: Balsa, Eivas (Quinta das Longas $)^{55}$, necrópoles do Padrãozinho e da Torre das Arcas, Museu de Évora, Museu de Marvão, Tróia,...56

Até hoje, não foram encontrados moldes de lucernas, que nos possam levar a pensar numa produção regional (hipótese que, todavia, não pomos de lado), motivo porque apontaremos as olarias do Norte de África como um possível centro produtor, opinião de Deneauve, no que diz respeito às lucernas de Cartago, especialmente para o seu tipo VIII B (2a série - "ateliers africains ou autres"). ${ }^{57}$

52 TRINDADE; FeRReiRA, cit. 12, p. 266, 268, 271,278.

53 Ponsich, M. - Les lampes romaines en terre cuite da la Maurétanie Tingitane, p. 42,43 .

54 A lucerna encontra-se exposta, apresentando as áreas em falta reconstituidas, arbitrariamente, com gesso.

55 Material inédito, em fase de estudo por um dos signatários (E.S.).

${ }_{56}$ É interessante verificar a ausência das Dressel-Lamboglia 30 B dos depósitos votivos descobertos em Portugal - Horta do Pinto, Peroguarda e Santa Bárbara. A sua inexistência é um testemunho válido de cronologias altas.

57 Deneauve, Jean - Lampes de Carthage, p. 81.

Conimbriga, 40 (2001) 237-280 


\section{LUCERNAS TARDIAS \\ (Sécs. IV e Y d.C.)}

O Museu possui no seu espólio duas lucernas que, pelas suas características, classificámos como pertencentes a finais do Império Romano: sécs. IV e V / VI d.C.

A primeira lucerna, n. ${ }^{\circ}$ 9, que já foi motivo de um pequeno artigo, publicado na década de 60, da autoria de Leonel Trindade e O. da Veiga Ferreira ${ }^{58}$, foi exumada na Quinta da Portucheira e tem como particularidade ser a simbiose entre uma lucerna de base plana e um pé alto (41 $\mathrm{mm}$ ) oco e cilíndrico (tendo este, como função, permitir uma melhor fixação a um possível candelabro). ${ }^{59}$ Elaborada a torno de oleiro, a partir de uma argila de cor alaranjada, parece-nos poder ser enquadrada na série de lucernas de terra sigillata hispânica tardia, embora não possua (ou possa ter perdido) o engobe. ${ }^{60}$ Possui um disco convexo, com orifício de alimentação bem centrado, separado da margo por uma canelura e decorado com pequenas incisões, que parecem querer representar volutas estilizadas. Seria munida de asa pequena, possivelmente triangular.

Até ao momento, Amaré foi a única investigadora que se debruçou sobre este tipo de lucernas, preocupando-se em estabelecer uma classificação, cronologia e difusão para as mesmas. No respeitante à tipologia, a lucerna da Portucheira parece, de facto, ser a combinação do Grupo IX com o X de Amaré. Excluímo-la do tipo X, visto este ser caracterizado por um disco navicolar, o que não acontece com este exemplar.61 Cronologicamente, deverá ser de produção de época baixo- imperial, podendo estender-se para mais além (época paleocristã?) se considerarmos a diacronia do exemplar de Burgos que os autores atri-

58 Trindade; FerReirA, cit. 12, p. 277, 278, est. I, II.

Estes investigadores consideram esta lucerna como de "inspiração púnica", o que tem levado outros autores a referirem-se à mesma como cartaginesa.

59 AmARÉ, cit. 24, p. 47,48.

60 AMARÉ, M. T. - Lucernas en terra sigillata hispánica, p. 800.

Em nota de pé de página, esta autora refere o facto de, em Tiermes, se ter exumado uma lucerna de "características semejantes... y non presenta ningún tipo de pigmento o engobe recubriéndola".

${ }_{61}$ Agradecemos à Dra. Maria Teresa Amaré Tafalla as sugestões dadas e a bibliografía fundamental para o estudo desta lucerna.

Conimbriga, 40 (2001) 237-280 
buem a época visigótica. ${ }^{62}$ No que concerne à difusão das lucernas tardias de "pé alto", apenas podemos apontar estações com este tipo de espolio em Espanha - La Estanca (Zaragoza), La Olmeda (Palencia) ${ }^{63}$, Hornillos del Camino (Burgos), $/ / / / \mathrm{d}^{64}$, Villa de Fortunatos e Zaragoza $^{65}$ - motivo que nos leva a afirmar ter esta produção um carácter estritamente ibérico ${ }^{66}$.

A segunda lucerna, n. ${ }^{\circ}$ 10, é um exemplar encontrado na Aldeia do Penedo e que consideramos ser um produto das olarias do Norte de Africa, mais concretamente, da Tunísia Central (Henchir-es-Srira), executada em argila vermelha do mesmo tipo da utilizada na produção dos serviços de terra sigillata africana clara C e D. Durante um longo período de tempo que vai do terceiro quartel do séc. IV d.C., até à segunda metade do séc. VI d.C., as lucernas tunisinas inundaram e conquistaram os mercados europeus e africanos, oferecendo uma variedade nova de formas e decorações de motivos ligados ao culto cristão. Este fragmento pertence ao tipo Atlante VIII C, lucerna de canal, que se distingue, morfologicamente, por ter urna asa compacta, colocada na vertical e com nervura central; orla plana e decorada com incisões; e disco decorado com concha em relevo. ${ }^{67}$ Devido às suas reduzidas dimensões, não podemos saber se o canal de que estava munida seria aberto ou fechado, motivo pelo qual não se nos afigurou fiável classificá-la dentro das variantes $\mathrm{Clc}$ (canal aberto) ou $\mathrm{C} 2 \mathrm{~d}$ (canal separado do disco).

O mapa de difusão destas duas variantes mostra-nos exemplares na Mauritânia Tingitânia (Cotta, Lixus, Tamuda e Volubilis) ${ }^{68}$, Tunísia (Cartago), Península Itálica (Graviscae - Tarquinia ${ }^{69}$, Fiesole (Museu

62 Martinez, M. - La nécropolis de Hornillos del Camino en el Museo, p. 28,29.

63 Palol, P.; Cortés, J. - La villa romana de La Olmeda, p. 152.

64 IBARRA, A. - Illici su situación y antigüedades, vasijas IV.

65 Paz Peralta, J. - Cerámica de mesa romana de los siglos III al VI d.C. en la provincia de Zaragoza.

66 Delgado, M. - Un cas de sigillée tardive régionale, p. 325.60.

Podemos encontrar, em Conímbriga, urna lucerna que se deve inserir no grupo IX de Amaré.

BAILEY, cit. 79. p. 271, Plate 54. Esta lucerna, de origem egípcia, apresenta um pé que se alarga, motivo que nos levou a não considerá-la como paralelo.

67 Anselmino, L.; Pavolini, C. - Terra sigillata: lucerne, p. 184-186, 192-198, tav. XCVI.10, XCVII.7.

68 Ponsich, cit. 53, p. 65, 106, 107.

69 HANOUNE, cit. 30 , p. 248, 249, PI. 7.45.

Conimbriga, 40 (2001) 237-280 
e escavações da Via Marina) ${ }^{70}$ e Roma $\left\{\right.$ Antiquarium Comunale ${ }^{71}$ ) e Espanha (La Morlaca - La Rioja ${ }^{72} 73$ e Atarse (Granada). Em Portugal, apenas dois arqueo-sitios forneceram lucernas deste tipo: Conimbriga, um pequeno fragmento ${ }^{72}$, e Tróia de Setúbal, com uma lucerna com-pleta em que a concha que decora o disco apresenta um desenho bastante diferente 74 Consideramos apenas, como paralelos perfeitos, as lucernas do Antiquarium Comunale, de Fiesole e de Graviscae.

\section{LUCERNAS PROVENIENTES DO ALENTEJO}

Trata-se de um conjunto constituido por três exemplares inteiros e por um fragmento de asa, de "tipo crescente". Não nos foi possível, através do trabalho de pesquisa que nos propusemos fazer, determinar o local, ou locais, onde estas lucernas poderão ter sido exumadas, visto que, nos breves estudos que foram efectuados, quer sobre a lucerna de cinco bicos ${ }^{75}$, quer sobre a lucerna com o disco decorado com um symplegma erótico, foi sempre omitido este tipo de informação. ${ }^{76}$

Intriga-nos a razão que terá levado Ricardo Belo e os seus companheiros de investigação a nunca se terem referido à lucerna de canal (.Firmalampe), que foi, certamente, adquirida/encontrada da mesma forma que foram as outras duas.

Embora estas lucernas sejam todas de tipo diferente, têm, no entanto, uma diacronia comum, de toda a segunda metade do séc. I d.C. (com maior incidência em épocas flávia e tardo-flávia).

Distingue-se, pela sua raridade, a lucerna de cinco bicos, $\mathrm{n}^{\circ} 11$, com a asa em forma de crescente lunar, decorada com figura mitológica.

Sobre o que Ricardo Belo, Leonel Trindade e Octávio da Veiga Ferreira $^{77}$ interpretaram como sendo o busto de Hércules com a maça

70 Squarzanti, S. - 7. Lucerne, p. 282, 284 (nota 31), 434, tav. V.37.

71 Pavolini, cit. 67, p. 196.

72 AmARÉ, M. T. - Lucernas romanas de La Rioja, p. 85, lam. III. 10.

73 Alarcão; Ponte, cit. 27, p. 107, PL XXIX.127.

74 MACIEL, M. J. - Arte romana Tardia e Paleocristã em Portugal, TR192-E, fig. 95.

75 Belo, A.; Trindade, L.; Ferreira, O. V. - Lucerna polimyxos do Museu de Torres Vedras, p. 315 a 317.

TRINDADE; FERREIRA, cit. 12, p. 265.

76 BeLo, cit. 2, p. 107-112, est. II.4.

77 Belo; Trindade; Ferreira, cit. 75, p. 315.

Conimbriga, 40 (2001) 237-280 
e o punhal, chegámos à conclusão de que estes investigadores ocorreram em erro, pois trata-se, na realidade, da figura de Júpiter na sua identificação com o culto capitolino, atendendo ao facto de que estes atributos não são mais a maça e o punhal, mas sim o raio estilizado e o ceptro ou a lança. Entre os vários paralelos para esta representação, destacamos os casos de fragmentos de asa, também em forma de crescente e decoradas com o busto de Júpiter, pertencentes à colecção do British Museum ${ }^{78}$, dos discos das lucernas de Neapel e da asa do Museu de Mainz. ${ }^{79}$ Nestes casos, Júpiter encontra-se sentado entre Juno e Minerva (a tríade capitolina), tendo na sua mão direita, que se encontra em posição de repouso $^{80}$, o raio e, na esquerda, o ceptro, composição que se repete em medalhões mandados cunhar por Trajano, Adriano e Antonino $\mathrm{Pio}^{81}$, todos datados da primeira metade do séc. II d.C. No que diz respeito à estrutura morfológica do disco, este tem um perfil côncavo, com orifício de alimentação pequeno e centrado, sem decoração. A orla, por sua vez, é preenchida por uma sucessão de três óvulos dispostos circularmente, separados entre si por um motivo vegetal estilizado (folha), que se prolonga para além do limite dos referidos óvulos. Embora tenhamos encontrado três exemplares do British Museum com decoração semelhante, aqueles diferem do Museu de Torres Vedras, pelo facto de a zona do margo estar dividida em dois semicírculos, apresentando, o superior, óvulos idênticos, e o inferior folhas de hera impressas que se ligam, entre si, em forma de semicoroa. Uma destas lucernas, com sete bicos, de proveniência desconhecida, assinada pelo oleiro C. Clodius Successus (com oficina em

78 Balley, cit. 40, p. 217-219, Plate 35, n. ${ }^{\circ}$ s 1039-1042.

Parece-nos ser o n. ${ }^{\circ} 1041$ aquele que se aproxima totalmente do exemplar do Museu de Torres Vedras.

79 Bergman, Marianne - Die Strahlen der Herrscher, p. 72, Tafel 17.

Menzel, Heinz - Antike Lampen, p. 28, 29, Abb. 26.11.

BAILEY, D. M. - A catalogue of the lamps in the British Museum. Ill - Roman Provincial Lamps, p. 423/4, Q. 3364. Esta lucerna, com a representação da tríade capitolina, não passa de uma falsificação efectuada, possivelmente, no séc. XIX.

80 Ao copiar a estatuária do Capitólio, o oleiro que produziu este molde atendendo ao facto de que teria de representar a figura de Júpiter de pé, teve necessidade de elevar a mão direita de forma que o atributo raio fosse bem visível, não tendo necessidade de fazer o mesmo com a mão esquerda.

81 Perdrizet, P. - Le Jupiter italique, p. 708-713.

Durrbach, F. - Hercule à Rome, p. 124-128.

Conimbriga, 40 (2001) 237-280 
Itália, em actividade, possivelmente, entre as épocas tardo-flaviana e antonina), possui a margo decorada com óvulos, que formam, no caso vertente, um círculo completo, o que a aproxima do esquema do exemplar que estudámos. ${ }^{\mathbf{2 2}}$ Os cinco bicos têm forma trapezoidal, com os orificios das mechas de diâmetro pequeno e idéntico, decorados com volutas estilizadas, que nos parecem ser um compromisso entre a concepção da lucerna Q1034 do British Museum (de bicos ogivais, com volutas duplas a separá-los) ${ }^{\mathbf{8 3}}$ e as Q1104 e Q1105, referidas no parágrafo anterior, com bicos de forma a tender para o cordiforme, onde as volutas estão ausentes. Como paralelo mais aproximado podemos indicar a lucerna com o n. ${ }^{\circ} 170$ do Museu Central de Mainz. ${ }^{84}$ A base, por sua vez, é plana, relativamente pequena, e delimitada por uma ranhura fina. No interior desta ranhura encontra-se impressa uma marca epigrafada em planta pedis, de leitura difícil, pois os três caracteres que conseguimos definir não são nítidos, denotando-se uma deficiência na aplicação da marca, que se vai reflectir na própria forma que, por vezes, nos parece ser rectangular. Esta lucerna, atendendo ao facto de possuir marca de oleiro em planta pedis (e não podendo estabelecer um paralelo com a terra sigillata itálica, onde este tipo de marca foi utilizado a partir de 15 d.C.), deverá ter uma cronologia que se estende, pelo menos, dos finais do principado de Tibério (altura em que aparece este tipo de configuração de marca em lucernas) ao limite máximo dos inícios dos Flávios (de acordo com as datações propostas por Bailey) ${ }^{85}$, encaixando, assim, no período mais lato proposto por Ponsich para o seu tipo de "anses-réflecteurs, croissant de lune" (tipo 3), do séc. I d.C. e referente a lucernas multibicos com este tipo de manubrium ${ }^{\mathbf{8 6}}$

A segunda lucerna $\mathrm{n} .^{\circ} 12$, proveniente de sítio indeterminado no Alentejo (Beja?), é, no respeitante à sua morfologia, um exemplar

82 BAILeY, cit. 40, p. 93, 94, 237-240, Plate 40.

83 BAILEY, cit. 40, p. 216, 217, Plate 34.

BAILEY, cit. 79, p. 426/7, Q 3375. Esta lucerna, que apresenta cinco bicos de tipo idêntico ao da nossa lucerna, não passa de uma falsificação efectuada, provavelmente, em Nápoles durante a primeira metade do séc. XIX.

84 MenZel, cit. 79, p. 35, 37, Abb. 170.

Menzel indica outras lucernas com a mesma morfologia respeitante aos bicos (museus de 1'Hermitage e Mainz, Pompeia e Herculano). O Museu de Luni tem em exposição uma lucerna (n. $\left.{ }^{\circ} 29\right)$, à qual falta a asa, com cinco bicos de forma arredondada.

85 BAILEY, cit. 83.

86 PONSICH, cit. 53, p.33,42,43. 
pouco vulgar nos espólios das estações romanas do actual territorio portugués. ${ }^{87}$

Pertence - dentro da classificação de Deneauve - ao subtipo VII $\mathrm{C}^{88}$, afastando-se do tipo original por possuir, na orla, duas pequenas saliências com formato de tronco de pirâmide (idênticas ás que se encontram na série referente ás lucernas de canal ou Firmalampen), mantendo o bico curto e arredondado, o qual é separado do disco por uma linha incisa (em sentido transversal), limitada, ñas extremidades, por dois pequenos círculos. A orla é lisa, o disco é, normalmente, decorado, tem orifício de arejamento e é munida de asa. Para a cena decorativa representada no disco, um symplegma erótico, já foi avançada uma descrição que achamos ter sido elaborada de forma a não ferir susceptibilidades, dada a época em que foi apresentada. ${ }^{89}$

O erotismo é um dos temas preferidos do repertório decorativo dos oleiros de Roma e suas províncias, em lucernas, em peças de terra sigillata e terracota, principalmente durante todo o séc. I d.C. e a primeira metade do séc. II d.C., caindo, entretanto, em desuso, com o advento do Cristianismo, tendo sido substituído por outros tipos de decoração, o que não impede que existam cenas eróticas mais bem elaboradas, em lucernas dos finais do séc. III d.C. ${ }^{\mathbf{9 0}}$

Quanto à decoração propriamente dita, esta apresenta uma mulher reclinada no seu leito, numa postura de êxtase, com o braço esquerdo apoiado e o direito sobre a cabeça, e com as pernas afastadas, possivelmente com sandálias, cujas fitas lhe sobem até metade da parte inferior da perna, enquanto que o seu companheiro, de joelhos, pratica o coito, segurando-lhe a perna esquerda à altura da coxa. Curiosamente, esta

87 Alarcão; Ponte, cit. 27, p. 101 (Conímbriga).

ALMEIDA, cit. 28, p. 164, lam. XXXVI (Conímbriga).

Franco, G. - Lucernas romanas, p. 175 (Faro).

MAIA, cit. 42, p. 97, 142 (Santa Bárbara).

Nolen, J. U. S. - Cerâmicas e vidros de Torre de Ares - Balsa, p. 44, 50, 213, Est. 6.

Embora o desenho não seja elucidativo, a autora classificou o exemplar com o n. ${ }^{\circ}$ lu - 45, como pertencente ao tipo Bailey P III, com uma cronologia compreendida entre os finais dos Flávios e o principado de Adriano.

88 DenEaUVE, cit. 57, p. 188-191.

89 BeLo, cit. 2, p. 107, 108.

90 SousA, E. M.; SepúlvedA, E. - Materiais inéditos da necrópole romana da Herdade da Barrosinha (Alcácer do Sal), p. 103-122.

Conímbriga, 40 (2001) 237-280 
representação tem mais paralelos, não em lucernas deste tipo ${ }^{91}$, mas noutras, de formas diferentes, embora com cronologia idêntica, como sejam os casos do exemplar do British Museum Q97992, dos de Cartago n. ${ }^{\circ}$ s 481 e $678^{93}$, o de Cotta, perto de Tanger ${ }^{94}$, do M.N.A.R. (Mérida) ${ }^{95}$, da Barrosinha e de Santa Bárbara. Na colecção de Cartago existe, por seu lado, urna lucerna idéntica, com o n. $^{\circ} 889$, em que, numa cena similar, a mulher se encontra reclinada, mas numa posição menos relaxante, mais direita (quase sentada), o que dá origem a urna contrae ção, quase em ângulo recto, da perna esquerda, não se vislumbrando a perna direita, que se encontra encoberta pelo tronco do seu companheiro, diminuindo, assim, a distância que separa as duas faces $\mathbf{9 6}$

Esta lucerna de Beja (?), tem urna base quase plana, demarcada por uma ranhura circular, no interior da qual existe urna marca incisa de NNAELVCI.

Deneauve determina, como período para a produção deste tipo, toda a segunda metade do séc. I d.C. e a primeira metade do séc. II d.C., baseando-se no facto de os oleiros que deixaram as suas marcas nestas lucernae terem também assinado a forma tipo.

Bailey, no entanto, aponta um intervalo mais fino, reduzindo-o para um período que decorre entre uma época post-pompeiana e o primeiro quartel do séc. II d.C., baseando-se no facto de não terem sido encontrados exemplares deste tipo nas escavações efectuadas na cidade vesuviana.

91 Deneauve, no estudo sobre as lucernas de Cartago, apresenta uma vintena de exemplares do subtipo VII C, dos quais apenas três com cenas eróticas, embora nenhum deles sirva de paralelo. Bailey conta apenas com oito do seu tipo P III (Q1319 a Q1326, p. 332-335), os quais possuem discos com outros motivos decorativos.

92 BAILEY, cit. 40, p. 64-71, 194, Plate 24.

Uma lista mais extensa de paralelos é apresentada, por este autor, na pag. 65 .

Não a mencionamos para não se tornar repetitivo.

93 Deneauve, cit. 57, p. 137, 162, 190, Pis. L, LXVII, LXXXI.

A lucerna com o ${ }^{\circ} 481$ é do tipo $\mathrm{V}$ A e contém a marca de oleiro CCLOSVC. Loeschcke apresenta, para Vindonissa, um disco com a mesma cena erótica.

94 Ponsich, cit. 53, p. 92, pi. XV.

95 N. ${ }^{\circ}$ de inventário: 11505; agradecemos ao Dr. Agostín Velázquez, Conservador do Museu, a informação que gentilmente nos cedeu sobre esta lucerna.

96 Deneauve, cit 57, P1. LXXXI. 


\section{FIRMALAMPEN}

A colecção do Museu Municipal de Torres Vedras possui um exemplar n. ${ }^{\circ} 13$ deste tipo de lucernas, também chamadas de canal, proveniente do Alentejo, a qual, embora completa, da asa apenas possui o arranque.

As Firmalampen são lucernas que se caracterizam por urna morfologia simples e funcional, tendo um corpo de forma troncocónica, urna orla larga, descaída para o exterior, onde se distinguem duas ou três saliências (neste último caso, uma em lugar da asa) em tronco de pirâmide. Estas saliências sugerem três diferentes interpretações: função de suspensão (com uma primeira fase de produção, em que são perfuradas), função decorativa e, por fim, uma função técnica, ou seja, a de facilitar o empilhamento aquando da cozedura nos fornos de cerâmica (lucernas munidas de três protuberâncias). O disco, normalmente côncavo, é, por vezes, decorado com máscaras teatrais, e com cabeças de Medusa ou de escravos, em relevo. As paredes do disco são quase verticais e delimitadas por uma canelura circular e alta. Esta pode acompanhar o desenho do canal, tornando-o aberto, circundando e definindo o bico.

Desta dicotomia, canelura circular/canal aberto, formaram-se as diversas variantes atribuídas a estas lucernas. ${ }^{97}$

Esta Firmalampe possui, como todas as outras, a característica das primeiras produções, que levou à atribuição deste nome, ou seja, uma marca de oleiro em relevo, inserida numa base delimitada, por duas caneluras, também relevadas, podendo-se ler o nome de LITOGENE.

Por sua vez, o disco é decorado com uma máscara que, devido ao facto de se encontrar bastante erodida, não nos parece ser do tipo teatral (comédia, sátira, tragédia), mas, possivelmente, relacionada com a representação de um jovem..$^{\mathbf{9 8}}$

97 Loeschcke atribuiu a estas lucernas os tipos IX, X e XK, quando estudou o material de Vindonissa, o que não invalidou que outros investigadores / ceramólogos, como Amaré, Bailey, Deneauve, Dressel, Ivanyi, Lamboglia, Ponsich, também tivessem atribuído uma classificação às Firmalampen.

98 Tentámos encontrar paralelos para a decoração do disco, mas não o conseguimos. A representação de um rapaz com cabeleira tipo onkos e barba, identificado por Bailey para a lucerna Q1164 (Plate 51), do British Museum, será, possivelmente, o paralelo mais aproximado.

Conimbriga, 40 (2001) 237-280 
No que diz respeito à produção das Firmalampen, esta estende-se por uma diacronia longa, que vai desde meados do séc. I d.C." até finais do séc. III d.C., prolongando-se, por vezes, pela centúria seguinte, tendo como floruit todo o séc. II d.C.

Devido à sua estrutura morfológica, bastante simples (ausência de molduras, disco decorado de uma forma simples e, por vezes, sem asa), são produzidas em grande quantidade, pois tornam-se de fácil execução e remoldagem, dando lugar a uma vasta difusão ${ }^{99}{ }^{100}$, numa área que se estende desde o Norte do Império (Londres), até ao Sul (Corinto), passando pelos acampamentos do limes renanos e do Danúbio, onde parecem ter sido muito populares entre os destacamentos legionários aí estacionados (Colonia Agrippinensis, Hofheim, Neuss, Nijmegen, Singidunum, Vindonissa, Weisnau). Ocorrem também nas Gálias (Avignon, Strasbourg, Vancluse, Vienne). Na Itália, a sua produção tem uma acentuada concentração no norte, na planície padana e no centro, regiões onde se localizavam as olarias que as produziram. Modena, Aquileia, Fiesole, Graviscae, Settefinestre, Capua e Pompeios, são arqueo-sitios onde foram igualmente encontradas lucernas deste tipo.

Nas escavações da Agora de Atenas foram encontradas lucernas de canal, de produção ática e de importação. ${ }^{101}$ Para oriente, em zonas mais afastadas do coração do Império, foram exumados exemplares na Dácia (Sarmizegetusa), na Dalmátia (Pule - Istria) e Asia (Ephesus). Curiosamente, nas províncias do Norte de África, a difusão das Firmalampen é escassa, quando comparada com exemplares coevos, de outros tipos. Ponsich não adianta nenhuma explicação para $o$ facto de apenas ter apresentado um exemplar para Volubilis e dois para Thamusida. ${ }^{102}$ Cartago parece ser uma excepção, pois Deneauve descreve

99 Amaré propõe esta data para o início da produção norte-itálica, baseando-se no trabalho de Buchi sobre as lucernas de Aquileia. Continua, no entanto, a aceitar a cronologia de Loeschcke, de época flávia, para os exemplares dos limes.

100 Não pretendemos fazer uma apresentação exaustiva dos vastos espólios museológicos com lucernas de canal, mas sim demonstrar a sua popularidade e as dificuldades que teve para se impor à concorrência que lhe era feita por outros tipos de lucernas fabricadas durante o mesmo período de tempo, num mercado tão vasto, mas por vezes bastante selectivo, como era o do Império Romano.

101 PerlzWEIG, Judith - The Athenian Agora, plate 5.120-121, plate 14,629-630.

102 PONSICH, cit. 53, p. 36.

Na região de Tanger (1970) e em Lixus (1981), não foram encontrados exemplares inteiros, ou mesmo fragmentos de Firmalampen.

Conimbriga, 40 (2001) 237-280 
nove lucernas do tipo IX A, indicando, para além destas, mais três a que chama "lampes dérivées des Firmalampen", tipo IX B.103 No que diz respeito à Península Ibérica, até finais da década de cinquenta, pensou-se que as lucernas de canal se encontravam ausentes. Com a intensificação das escavações arqueológicas e o subsequente estudo dos espólios assim obtidos, quer em Portugal (Conímbriga) quer em Espanha (Astorga, Mérida, Tarrazona), conseguiu-se estabelecer um vasto mapa de difusão.

Apontaremos, para o território português, os exemplares que conseguimos apurar da bibliografia consultada. Para além da lucerna de Torres Vedras, de proveniência alentejana, encontramos Firmalampen ${ }^{104}$ na Aldeia do Bispo, Balsa ${ }^{105}$, Beja, Conimbriga ${ }^{106}$, no concelho de Lagos, Casa do Procurador ou Sítio da Chaminé Transtagana ${ }^{107}$, Monserrate (Sintra) ${ }^{108}$, Horta do Pinto (Faro) ${ }^{109}{ }^{110}$, Sabroso, Teatro romano de Lisboa no, Valadares e de local indeterminado no Algarve. Em relação a Tróia de Setúbal, para além de um exemplar que apresenta apenas o disco e que se encontra inédito, Maria Elisabeth Costa, na sua tese de licenciatura, apresenta os exemplares n. ${ }^{\circ}$ s 97 e 98 como sendo Firmalampen do tipo Deneauve IX A (= Dressel-Lamboglia 5C e D). Pensamos tratar-se de formas derivadas, pois possuem a orla decorada com rosetas, não apresentando as duas protuberâncias que tornam estas lucernas tão características. Uma classificação como Deneauve IX B parece-nos aqui mais adequada. O mesmo acontece com o n. ${ }^{\circ}$ 95, que deveria ser incluído neste grupo, pois apresenta um canal bem definido

103 Deneauve, cit. 57, p. 208, pl. XCIII.

Quatro destas lucernas provêem de enterramentos do "Cemitério dos Oficiais".

$104 p_{\text {ara os }} i_{\text {oca }}$ is sem nota de rodapé, veja-se ALMEIDA, cit. 28, p. 166,167,193, 194, Est. XXXVII, XLVII.

105 NOLEN, cit. 86, p. 43, est. 5, lu-37.

Uma lucerna de proveniência desconhecida (Alentejo ?) da colecção Bustorff Silva, Bus. 197, foi estudada por Nolen, aquando da exposição "Um gosto privado, um olhar público".

106BELCHIOR, cit. 41, p. 70-72, Est. XXI, XXII.

Alarcão; Ponte, cit. 27, p. 106, 107, Planche XXIX.

107 PIXA, L. - Um conjunto de lucernas da Casa do Procurador (Aljustrel), lucerna $n .^{\circ} 5$.

${ }_{108}$ CIL II 6256, 44 B - STROBILI em lucerna.

109 Franco, cit. 86, p. 175, 14.42.

110 Exemplar em estudo por um dos signatários (E.S.) e António Dias Diogo.

Conimbriga, 40 (2001) 237-280 
e ligado directamente ao disco, o que vai implicar urna total discrepância com a forma que lhe foi atribuída (Loeschcke II). ${ }^{111}$

Por sua vez, o panorama da difusão das lucernas de canal, em Espanha, apresenta uma variante em relação ao que apontámos para Portugal $^{112}$, pois as produções locais aparecem lado a lado com as importações da península itálica. A norte, em Asturica Augusta (Astorga, na província de Léon), foram encontrados moldes de Firmalampen, de qualidade não muito apurada, que serviriam apenas para abastecer o mercado local. Amaré coloca a sua produção num período compreendido entre meados do séc. I d.C. e o séc. II. ${ }^{113}$ Para Este, na zona do Ebro, uma outra olaria, localizada em Turiaso (Tarazona), produziu vários tipos de lucernas, entre os quais as Dressel-Lamboglia 5/6. Mais uma vez, a sua produção seria dirigida às necessidades da zona de influência da cidade e a uma clientela de gosto pouco requintado, pois outras formas que apresentam discos decorados e produzidas pelo mesmo forno denotam uma impressão mal conseguida, o que indicia a utilização de moldes deficientes, mal limpos ou não originais. ${ }^{114} \mathrm{Na}$ Lusitânia, em Augusta Emerita, nas escavações efectuadas na olaria da Calle Constantino, foram encontrados inúmeros fragmentos de peças rejeitadas devido a acidentes de fabrico na cozedura, entre os quais se encontra uma orla de Firmalampe.

111 Sobre este parágrafo remete-se para:

CostA, cit. 43, p. 145-150, est. XXXIII, XXXIV, LXXIV.2, LXXXI.4.

Existe, também, um exemplar deste tipo em Braga (Museu D. Diogo de Sousa).

112 Embora em Alcácer do Sal, Braga, Conímbriga, Quinta do Rouxinol, Setúbal e Serpa se tenham encontrado moldes para fabrico de lucernas, nenhuma das olarias a eles associadas produziram Firmalampen. Veja-se:

BeLCHIOR, cit. 41, p. 78, Est. XXIV.3, Est. A.

DuARTE, A.; RAposo, J. - Elementos para a caracterização das produções anfóricas da Quinta do Rouxinol, p. 237-247.

Silva, C. T.; Soares, A. C. - A Praça do Bocage "Setúbal" na época romana, p. 268,276 ,est. V, 45 .

SouSA, J. R. - Acerca de um molde de lucernas, p. 309-311.

TeiXeirA, A.; Silva, R. B. - Molde de lucerna do Sítio do Nicolau, p. 147 - 152.

VianA, A. - Alcácer do Sal, p. 9, 10, fig. 11, 12.

ViAnA, A. - Algumas noções elementares de Arqueologia prática, p. 114, 115, fig. 131, 132 .

113 Amaré, M. T. - Una producción de lucernas en Asturica Augusta, p. 273 - 285.

114 AmARÉ, M. T. (et al.) - Avance al estudio de un possible alfar romano de Tarrazona.

Beltrán, M. - Guia de la cerámica romana. 19 - Lucernas, p. 261-277. 
Em relação a esta produção, põe-se hoje em dúvida que os exemplares até agora considerados como originários de outros centros oleiros, não tenham sido produzidos em Mérida e comercializados, pelo menos, por toda a Lusitânia.115 Para além destes três locais, em que a produção estava dirigida a um escoamento local, iremos encontrar uma vasta rede de consumo, que se estende por toda a Tarraconense e Bética. Complutum, Dueñas, Herrera de Pisuerga, Raimat - Lleida, Rosinos de Vidríales, Segobriga, Tolegassos - Ampúrias, Italica, Carteia, constituem apenas uma pequena lista.

Entre as reservas do Museu, existe também um fragmento de asa em forma de crescente lunar (n. $\left.{ }^{\circ} 14\right)$. Não podemos indicar a que lucerna pertenceria, razão por que tivemos de recorrer às tipologias existentes e, assim, estabelecer uma possível correspondência, asa / lucerna. Ponsich considera este tipo de asas como pertencentes a lucernas decoradas com volutas, ou com mais de um bico, chamando-lhe "asas reflectores" e apresentando-as lisas ou decoradas. ${ }^{\mathbf{1 1 6}}$ No entanto, vários autores, entre os quais Deneauve ${ }^{117}$, não lhes reconhecem esta funcionalidade, preferindo chamar-lhes "plásticas", o que não impede, como é no caso de Cartago, que estejam associadas à mesma forma das lucernas indicadas. Nas colecções do British Museum, aquelas pertencem a lucernas dos tipos Bailey $\mathrm{D}, \mathrm{H}, \mathrm{L}, \mathrm{e} \mathrm{O}^{118}$, produzidas em Itália (Pozzuoli) durante um intervalo de tempo balizado pelos anos 38 / 42 d.C. e a segunda década do séc. II d.C. Atendendo à fragilidade desta asa, que se pode considerar ornamental, é vulgar encontrarem-se, nos espólios de estações romanas, fragmentos que estão normalmente dissociados do corpo da lucerna a que pertenceriam, e que terão cronologias idênticas às que apontámos no parágrafo anterior.

115 Rodriguez MARtin, F. G. - Materiales de un alfar emeritense.

116 Ponsich, cit. 53, p. 42-43 (tipo Ponsich 3).

No que diz respeito à decoração, veja-se a descrição referente à lucerna de cinco bicos.

117 Deneauve, cit. 57, p. 79.

Type V B - lampes à plusieurs bees et lampes à anse plastique, p. 145-149, Pl. LVI - LIX.

$118=$ Broneer XXI.

Conimbriga, 40 (2001) 237-280 


\section{MARCAS DE OLEIRO}

Como acontece com outras produções cerâmicas, as lucernas podem apresentar diversos tipos de marcas apostas quer no disco, quer na base, quer ainda na asa.

A zona do disco foi escolhida pelos oleiros romanos e das províncias do Império Romano do séc. I e II d.C. para transmitirem mensagens relacionadas com desejos de felicidade para o Ano Novo ANNVM NOVVM FAVSTVM FELICEM TIBI, para relembrarem nomes de heróis dos anfiteatros (Decirius, Baebius, Sabinus...) e dos hipódromos CAquilo, Priscian..), e para fazerem propaganda imperial $O B$ CIVIS SERV; FIDES PVBLICA; LVCER PVBLICAM ${ }^{9}$

No que concerne ás marcas ñas bases 119 120, estas serviriam, possivelmente, para individualizar produções podendo ser epigrafadas (com letras em relevo, incisas ou grafitadas), não nominais (efectuadas em planta pedis, quadrados e/ou pequenos rectángulos), ou com representações várias, que vão desde os motivos geométricos aos vegetalistas. Muito raramente se encontram iniciais ou possíveis marcas, na orla ou nas paredes laterais do infundibulum, as quais poderão indicar, no caso das iniciais, possíveis controles de produção.

O total das lucernas do Museu Municipal estudadas apresenta seis marcas de oleiro, das quais quatro epigrafadas (duas em relevo e duas incisas), uma com motivo vegetalista (palma) e uma possível marca aplicada na parede lateral do infundibulum.

\section{MARCAS EPIGRÁFICAS}

ERAC (LID) - Marca incisa, possivelmente, entre dois círculos, incompleta, faltando-lhe a parte final, e pertencente a um pequeno fragmento de base de lucerna (n. $\left.{ }^{\circ} 15\right)$, da qual não podemos indicar o tipo.

HERACLIDES foi um oleiro romano, que laborou durante a época an tonina (período final) ou no início da época severiana. Encontramos esta marca, geralmente em lucernas do tipo Bailey Q (= Dressel-

119 BAILEY, cit. 40, p. 110, 111, fig. 112.

120 No nosso estudo, a percentagem de lucernas com marcas de oleiro representa $40 \%$ do total, o que a afasta da média de $15 \%$ que se poderá encontrar, normalmente, para outros sítios arqueológicos.

Conimbriga, 40 (2001) 237-280 
-Lamboglia 27) $)^{121}$ e numa Firmalampe, assinada por este oleiro, de Graviscae $^{122}$, privilegiando motivos decorativos do disco, tais como Amores, Diana Wenetrix, Luna e Sol, Leda, cenas eróticas, grotescas, e corridas de carros. Para além do exemplar da aldeia do Penedo, único em Portugal, que tenhamos conhecimento, encontrámos lucernas com a sua marca em Fiesole ${ }^{123}$, Ostia (Terme del Nuatatore), e Graviscae. Os sete exemplares do British Museum são de proveniência desconhecida, o que invalida a possibilidade de se elaborar um mapa de difusão. No que diz respeito à epigrafia, os paralelos mais próximos parecem ser os dos n. ${ }^{\circ}$ S Q1359 e Q1400 do Museu Britânico, e o de Graviscae.

LITOGENE - Marca (n. ${ }^{\circ}$ 13a) em relevo, de excelente execução, com o NE em nexo, pertencente a urna lucerna de canal com asa. ${ }^{\mathbf{1 2 4}}$

LITOGENES foi um oleiro romano que exerceu a sua actividade durante o período que vai desde os meados do séc. I d.C. até aos inicios do séc. II d.C. Tendo tido urna actividade bastante prolífera na Itália, na região do limes danubiano \{Raetia Noricum, Pannonia, Dalmácia e Dácia) e no renano (Vindonissa), onde foram encontrados testemunhos com a sua marca é, no entanto, pouco conhecido nas províncias do sul do Império, pois apenas temos referências ao seu nome na Gália Narbonense, em África (Cartago) ${ }^{\mathbf{1 2 5}}$ e Portugal (a lucerna do Mercado de Torres Vedras será a única encontrada no território português).

Terá como paralelos uma lucerna de Vindonissa, do tipo Loeschcke X 126, a dos museus de Bona, de Parma e das Termas de Diocleciano (intrusão?).

121 Balley, cit. 40, p. 94, 354-357, 369, 374, plate 78, 79, 84, 86.

122 HANOUNE, cit. 30, p. 242, pl. 4.18.

123 SQUARZANTI, cit. 70, p. 283, nota 22.

124 Agradecemos à Dra. Paula Morgado a ajuda que nos deu, relativamente a pistas sobre esta marca.

Sobre este oleiro veja-se:

LOESCHCKE, cit. 39, p. 264 (nota 186), 265, 283, 284, 433, 434, taf. XIX, 850, 852,853 .

Menzel, cit. 79, p. 62 (n. $\left.{ }^{\circ} .370\right)$, p. 64, Abb. 51.1.

125 Deneauve, cit. 57, p. 90, 209.1030.

126 Das marcas que Loeschcke apresenta para Vindonissa, apenas uma, a n. ${ }^{\circ} 854$, é munida de asa e tem o NE em nexo, como o nosso exemplar. No entanto, por terminar em S, não a podemos apresentar como paralelo.

Conimbriga, 40 (2001) 237-280 
NNAELVCI - Marca $\left(\right.$ n. $^{\circ}$ 12a) incisa, pertencente a urna lucerna do tipo Deneauve VII C.

N(VMERIVS ?) NAE(VIVS) LVCI(VS ? / ANIVS ?), (possível leitura da marca) $)^{127}$, corresponde a um oleiro que deveria ter a sua oficina localizada algures na Itália central, tendo laborado durante todo o final do séc. I d.C. (época flávia tardia) e o principado de Adriano. A sua produção, principalmente do tipo Dressel-Lamboglia 20, tem uma difusão que abrange todo o Império Romano, tendo como pólo principal a Itália (Roma). É possível encontrarem-se exemplares com esta marca na Gália, nas Germânias, na Sardenha, em Espanha (Los Báñales - Aragon, Torre Llauder - Mataró), em África (Cartago - Necrópole dos Oficiais) ${ }^{\mathbf{1 2 8}}$ e em Portugal (Beja (?) e Santa Bárbara - Castro Verde) ${ }^{129}$. A temática dos discos das lucernas fabricadas por este oleiro representa normalmente cenas relacionadas com o culto de Mercúrio (lucernas Q1280 e Q1302 do British Museum), luta de Hércules com o Dragão (Los Báñales), gladiadores (Cartago), e motivos vegetalistas.

O symplegma erótico, embora popular para a época, afasta-se, assim, destes temas. Como paralelos, no respeitante à morfologia e epigrafia, indicaremos as lucernas de Santa Bárbara, com os n. ${ }^{\circ}$ Lu553 a 556.

ÇTP - Marca (n. ${ }^{\circ} 1$ la), em planta pedis, cavada com letras em relevo, sobre lucerna de cinco bicos. Pensamos poder atribuir a este oleiro centro-itálico a marca acima indicada, depois de a termos comparado com idênticas marcas apresentadas por Bailey. A possibilidade de escolha foi vasta, na medida em que seis oleiros (perto de uma vintena e meia de exemplares) estão catalogados e identificados, como tendo utilizado a forma planta pedis para marcarem as suas produções. ${ }^{130}$ Utilizámos como critério de escolha o tipo morfológico da lucerna, a forma da asa, a decoração da orla e a diacronia correspondente ao

127 AmARÉ, cit. 24, p. 105, fig. 239.218.

128 DenEaUVe, cit. 57, p. 91,172, pl. LXXI .747.

Curiosamente, este autor apresenta uma leitura diferente para esta marca, onde o N inicial é substituído por M (CIL VIII, 22644 - 232).

129 O espólio de Santa Bárbara apresenta, para além das Dressel-Lamboglia 20, exemplares morfologicamente idênticos à nossa lucerna (Deneauve VII C).

${ }_{130}$ C CLOD, MYRO, N N A, C T P, L V C, P V F. 
período de laboração. ${ }^{131}$ Dois oleiros tiveram a nossa preferência: NNA e CTP. Embora NNA nos desse uma leitura que poderia ser aceitável, achámos que a ausência de orla decorada (Q1031 do British Museum) e a existência, na nossa marca, de um $\mathrm{T}$ que de maneira nenhuma pode ser um $\mathrm{N}$, não nos serviria de paralelo, motivo pelo qual escolhemos CTP, na variante apresentada para a lucerna Q1033, com origem em Pozzuoli. ${ }^{132}$

Possível marca - Marca (n. ${ }^{\circ}$ 6a) cavada e efectuada em relevo, situada na parede esquerda do infundibulum, e ilegível. Apenas em contraluz se consegue distinguir um conjunto de caracteres (três letras?) pouco perceptíveis, mesmo quando se obtém o seu negativo. ${ }^{133}$ Embora a aposição de letras, números e siglas, na orla e no bico não tenha sido muito normal, não conseguimos encontrar um possível paralelo, devido ao facto apontado anteriormente. Apenas a mero título informativo indicamos dois exemplos de lucernas com epigrafia no bico e na orla: Peroguarda ${ }^{\mathbf{1 3 4}}$ e Aldeia do Bispo - Penamacor. ${ }^{\mathbf{1 3 5}}$

Palma (sete folhas) - Marca (.$^{\circ}$ 2a) incisa, em base de lucerna do tipo Dressel - Lamboglia 20. Esta marca aparece, normalmente, aplicada em lucernas tardias do tipo Dressel 30 e 31136. No entanto, o exemplar do Mercado Municipal de Torres Vedras sugere uma diacronia dos finais do séc. I d.C., inícios do II d.C. Em Portugal, encontra-se bastante difundida, e por vezes associada a iniciais. Trata-se, talvez, de uma produção local, possivelmente das olarias do estuário do Sado, visto ter uma difusão que se vai polarizar na zona de influência comer-

131 Lucernas com mais de um bico; asa em forma de crescente; orla decorada com óvulos; produzidas entre 40 e 80 d.C.

132 BAILEY, cit. 40, fig. 107, 109, p. 215, 216.

Veja-se também:

BALIL, A. - Estudios sobre lucernas romanas; III Marcas de ceramistas in planta pedis, p. 16-18.

${ }_{133}$ Agradecemos ao Dr. Guilherme Cardoso o ter-nos alertado para este facto.

134 Ribeiro, F., cit. 45, n. ${ }^{\circ}$ 17, 23, 24.

135 Leitão, M.; Ponte, S. - Lucernas romanas do Museu Francisco Tavares Proença Júnior, p. 150.

136 Elisabeth Cabral sugere, para além destas, a existência de lucernas do tipo Dressel 9, com esta marca.

Conimbriga, 40 (2001) 237-280 
cial deste rio. 137138139 Localizam-se, preferencialmente, a Sul os arque-osítios com lucernas marcadas com este símbolo: Algarve ${ }^{138}$ (?), Balsa ${ }^{139}$, Barrosinha, Torre das Arcas - Elvas 140, Torre de Palma e Tróia, entre outras. Em Santa Bárbara, a lucerna Lu-243 apresenta uma combinação pouco vulgar em que urna marca em planta pedis está associada à palma.

Tendo estas lucernas sido exumadas nas áreas da Aldeia do Penedo (Penedo), Mercado Municipal, Quinta da Portucheira, Quinta de São Gião e Serra de S. Julião, abrangendo, cronologicamente, um vasto período de tempo, pode concluir-se que:

- A ocupação romana da villa do Penedo possui uma diacronia da segunda metade do séc. I d.C. até aos sécs. V/VI d.C., como provam os exemplares estudados e outros tipos de cerâmica provenientes deste local. A villa da Serra de S. Julião apresenta apenas uma peça (asa), o que nos levou a colocar a sua cronologia no séc. I / II d.C., o que não obsta a que este sítio apresente numismas e epígrafes para o intervalo compreendido entre meados do séc. II a.C. e 150 d.C. ${ }^{141}$

A necrópole da Quinta da Portucheira foi utilizada desde a época tardo-republicana, até finais do séc. V d.C. O seu espólio (cerâmica fina, epigrafia e numisma) é indicador válido deste período, o qual podemos adicionar às lucernas estudadas. $O$ arque-osítio indicado como necrópole, situado na zona do Mercado Municipal142, terá sido utilizado durante o séc. II d.C.

- A villa romana da Quinta de São Gião não será apenas uma villa rústica, mas sim um habitat com a sua necrópole. Embora não

${ }_{137}$ BAILEY, cit. 40, fig. Ill Q1432 - Apresenta apenas um caso com esta marca em produções itálicas.

Quando um dos signatários (E. S.) estudou, com Élvio Melim de Sousa, a colecção dos Comendadores Nunes Correia referente ao espólio da Barrosinha, adiantou-se a hipótese da lucerna erótica com a marca de três palmas e duas letras poder ser de produção emeritense, o que, presentemente, se põe em dúvida, atendendo a informações posteriores de um dos directores do Museu Pedro Nunes (Fernando Gomes), que as coloca como um produto final dos fornos da Barrosinha, tal como o exemplar exumado no Pinheiro (Alcácer do Sal).

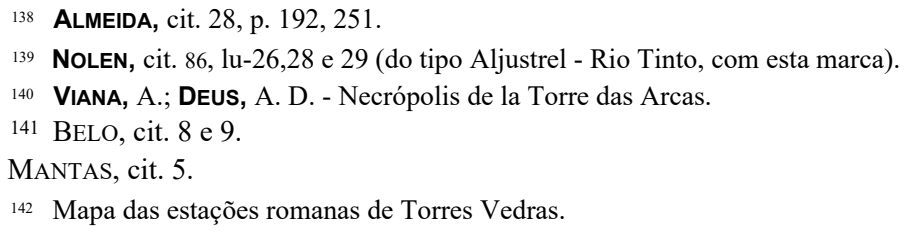

Conimbriga, 40 (2001) 237-280 
saibamos a sua dimensão, o tipo de vestígios superficiais - lucernas em bronze, moedas, anéis, ara, asa de sítula, epígrafes, silhares ${ }^{143}$,vidros, e cerâmica vária - leva-nos a enquadrá-la no que J. Alarcão define como villa ${ }^{144}$. A sua ocupação terá uma diacronia de início, pelo menos, da época dos júlios-cláudios e com um final que não nos é possível determinar, devido à escassez de informação.

\section{CATÁLOGO}

\section{ABREVIATURAS}

a - asa; b - base; c - central; d - disco; o - orla; $\mathrm{p}$ - pé; $\mathrm{t}$ - total;

e.n.p. - elementos não plásticos; $\mathrm{n} / \mathrm{d}$ - não determinável. Medidas em mm.

Desenhos e tintagem dos autores.

\section{N. ${ }^{\circ} 1(\mathrm{QP} / 61)$}

Fragmento de lucerna - Tipo Dressel-Lamboglia 2.

Pasta - pouco homogénea, pouco depurada, com e.n.p. de pequenas e médias dimensões (calcites, quartzitos e micas), muito branda, muito porosa, com fractura irregular, de cor alaranjada apresentando uma zona bicolor junto à aleta de núcleo beige, Munsell 7.5 YR $\quad 6 / 6$ (reddish yellow).

Engobe - tipo "verniz", relativamente espesso, brilhante, de cor vermelho acastanhado, Munsell 10 R 4/6 (red).

Medidas - altura - 30; diámetro - b. 44; espessura - b. 3,5; reservatório: 3 .

Cronologia - meados do séc. I a.C. até ao primeiro decénio do séc. I d.C.

\section{N. ${ }^{\circ} 2(T V M / 1)$}

Lucerna - Tipo Dressel-Lamboglia 20; Loeschcke VIII; Ponsich

III B 1; Deneauve VII A.

- Asa Ponsich 7/8.

Pasta - homogénea, compacta, moderadamente dura, não porosa, de cor "café com leite" claro, Munsell 10 YR 7/2 (light gray), com e.n.p. em pouca quantidade (calcites).

143 Madeira Torres refere-se a eles como "cantaria lavrada".

144 ALARCÃo, Jorge - Paisagem rural romana e alto-medieval em Portugal.

Conimbriga, 40 (2001) 237-280 
Engobe - dois pequenos pontos com engobe, pouco espesso e possivelmente brilhante, de cor vermelho/acastanhado, Munsell 2.5 YR 4/6 (dark red).

Medidas - comprimento - t. 118; d. 60; bico 26; largura - c. 78; o. 11; altura - t. 52; centro d. 27; o. 30; a. 51; diâmetro - d. 56; b. 49; orifício bico 15; orifício d. 10; orifício asa: 19,5; espessura - a. 12/16; posição da asa: ligeiramente descentrada para a esquerda.

Motivos decorativos - cena de venatio entre animais: javali a ser atacado por um cão.

Marca de oleiro - Palma (sete folhas).

Cronologia - tardo-flaviana (quarto quartel do séc. I d.C. - primeira metade do séc. II d.C).

\section{N. ${ }^{\circ} 3(\mathbf{A P} / \mathbf{1 8 3})$}

Lucerna - Tipo Dressel-Lamboglia 20; Deneauve VII A - Asa Ponsich 8.

Pasta - homogénea, compacta, moderadamente dura, porosa, com e.n.p. abundantes de reduzidas dimensões (cerâmica moída, pontos negros, micas), de cor castanho claro, Munsell 7.5 YR 6/6 (reddish yellow).

Engobe - superfície não engobada, provavelmente polida.

Medidas - comprimento - 103; largura - o. 22/24; diâmetro - orifício asa: 13,5; espessura - 10/14; posição da asa: centrada (possivelmente).

Motivos decorativos - disco talvez decorado.

Cronologia - segunda metade do séc. I d.C. / primeira metade do séc. II d.C.

\section{N. ${ }^{\circ} 4$ (SEJ/28)}

Asa - Tipo Ponsich 7/8.

Pasta - compacta, homogénea, branda, porosa, com e.n.p. pouco visíveis (micas), de cor beige, Munsell 10 YR 8/3 (very pale brown).

Engobe - bastante erodido, moderadamente espesso, possivelmente brilhante, de cor castanho claro, Munsell 7.5 YR 4/4 (brown), com manchas de castanho muito escuro, Munsell 7.5 YR 3/2 (dark brown).

Medidas - espessura - 8/10,5; diâmetro - orifício asa: 10/11,5.

Cronologia - desde o terceiro quartel do séc. I d.C. até finais do séc. II d.C. 
N. ${ }^{5}$ (AP/58)

Lucerna - Tipo Dressel-Lamboglia 28 A $=$ Deneauve VIII C. Asa - Ponsich 7/8.

Pasta - de má qualidade, pouco compacta, muito branda, porosa, com e.n.p. de tamanho médio e grande, à superficie em grande percentagem (pontos negros, calcites, quartzitos em grande quantidade, poucas micas de dimensões reduzidas e elementos cerâmicos), de cor bege-alaranjada, Munsell 5 YR 7/3 (pink).

Engobe - possivelmente engobada, apresentando zonas com tonalidades carmins, Munsell 2.5 YR 6/8 (red).

Medidas - comprimento - t. 103; d. 50; bico 29; largura - c. 72; o. 12/14; altura - t. 54; centro d. 26; o. 36; a. 54; diámetro - d. 46; b. 45; orificio bico 14; orificio d. $\mathrm{n} / \mathrm{d}$; orificio asa: 7; espessura - a. 12/10; posição da asa: centrada.

Motivos decorativos - perolada na orla; espiga na asa.

Cronologia - inícios do séc. III d.C.

\section{N. ${ }^{\circ} 6(\mathrm{AP} / \mathbf{1 8 4})$}

Lucerna - Tipo Dressel-Lamboglia 30A; Deneauve VIIIB; Ponsich IIIC; Amaré 3D. Asa - Ponsich 8.

Pasta - pouco homogénea, compacta, dura, pouco porosa, com e.n.p. em abundância (quartzitos, calcites, pontos negros e micas de reduzidas dimensões), de cor beige acastanhado, Munsell 5 YR 6/6 (reddish yellow).

Engobe - marcas de cor laranja, Munsell 2.5 YR 6/8 (red), principalmente na asa (manchas que se encontram também sobre a zona de restauro).

Medidas (aproximadas atendendo ao restauro) - comprimento -1. 124; d. 60; bico 30; largura - c. 84; o. 12; - t. 55; centro d. 26;

o. 33 ; a. 55 ; diámetro - d. 57 ; b.: $\mathrm{n} / \mathrm{d}$; orificio bico 17 ; orificio d. 11; orificio asa 16; espessura - a. 12 (no topo); posição da asa: n/d.

Motivos decorativos - busto de Hélios.

Cronologia - séc. Ill d.C.

\section{N. 7 (AP/185)}

Lucerna - Tipo Dressel-Lamboglia 30 B. Asa - Ponsich 9.

Pasta - muito compacta, moderadamente dura, não porosa, com e.n.p de pequenas dimensões, destacando-se muitos pontos ferruginosos e micas de reduzidíssimas dimensões, de cor ocre, Munsell 7.5 YR 8/2.5 (pinkish white). 
Engobe - restos na orla e na base; espesso ligeiramente escamado, parecendo baço de cor "vinho tinto", Munsell 10 R 4/4 (weak red).

Medidas - comprimento -1. 88; d. 28; bico 30; largura - c. 65; o. 18; altura - t. 47; centro d. 35 ; o. 40; a. 34; diámetro - d. 28; b. 35; orificio bico 17; orificio d. 15; espessura - a. 16; posição da asa: ligeiramente para a direita.

Motivos decorativos - perolada na orla.

Cronologia - segunda metade do séc. III / séc. IV d.C.

\section{$\mathrm{N} .^{\circ} 8(\mathrm{QP} / \mathbf{8 3})$}

Lucerna-Tipo Dressel-Lamboglia 30 B; Deneauve XI A - Sem asa.

Pasta - de má qualidade, muito grosseira, com inúmeros e.n.p. de grandes dimensões (quartzos, quartzo leitoso, hematites, feldspatos e pequenas partículas de mica), branda, porosa, de cor creme, Munsell

7.5 YR $8 / 4$ (pink).

Engobe - possivelmente engobada, embora não se possa indicar a cor.

Medidas - comprimento - bico 25; largura - c. 82; o. 22;

-1. 39; centro d. 34; diâmetro - d. 40; b. 43; orifício bico 19.

Motivos decorativos - perolada na orla.

Cronologia - segunda metade do séc. III / séc. IV d.C.

\section{N. ${ }^{\circ} 9(\mathrm{QP} / 84)$}

Lucerna - Tipo Amaré IX/X. Asa - possivelmente Ponsich 9.

Pasta - muito pouco depurada, com muitos e.n.p. de pequenas e médias dimensões (quartzo leitoso, feldspatos, quartzitos, micas e pontos negros), branda, porosa, de cor laranja-avermelhada, Munsell

2.5 YR 5/8 (red).

Engobe - não apresenta vestígios de engobe.

Medidas - comprimento - t. 79; d. 41; bico 20; largura - c. 72,5; o. 9; altura - t. 84 / 79; centro d. 32,5; o. 65; a.: n/d; p. 41,5 a 44; diâmetro - d. 56; b. 34; p. 38; orifício bico 19; orifício d.14; espessura - a.: n/d; posição da asa: possivelmente centrada. simuladas).

Motivos decorativos - incisões tipo "bago de arroz" (volutas

Cronologia - séc. IV d.C. a princípios do séc. V d.C. 


\section{N. ${ }^{\circ} 10(\mathrm{AP} / 81)$}

Lucerna - Tipo Atlante VIII Clc ou VIII C2d; Deneauve XII; Dressel-Lamboglia 31; Ponsich IV B; Amaré V 1 B. Asa - Ponsich 9.

Pasta - compacta, muito dura, não porosa, com e.n.p. geralmente de pequenas dimensões (calcites, micas, feldspatos e cerâmica moída), de cor de tijolo, Munsell 10 R 5/8 (red).

Engobe - moderadamente espesso, uniforme, pouco brilhante, de cor de tijolo, Munsell 2.5 YR 4/8 (dark red).

Medidas - altura do frag. - a. 32; espessura - a. 7/21; reservatorio: 4.

Motivos decorativos - concha estilizada em relevo.

Cronologia - terceiro quartel do séc. IV d.C., possivelmente até finais do séc. VI d.C.

\section{N. ${ }^{\circ} 11\left(\mathbf{N}^{\circ}\right.$ Inv. 1232)}

Lucerna - Tipo Broneer XXI . Asa - Ponsich 3.

Pasta - pouco homogénea, compacta, moderadamente dura, não porosa, de cor ocre clara, Munsell 10 YR 8/3 (very pale brown), com e.n.p. de tamanho reduzido (calcites e pontos negros).

Engobe - moderadamente espesso, escamado, matizado na gama dos castanhos, Munsell 10 YR $3 / 1$ (very dark gray), Munsell 2.5 YR 5/8 (red), Munsell 10 YR 6/4 (light yellowish brown), e com reflexos metálicos.

Medidas - comprimento: t. 162; d. 46; bicos (sentido ponteiros do relógio) $\mathrm{BI}=40, \mathrm{~B} 2=43, \mathrm{~B} 3=41, \mathrm{~B} 4=41, \mathrm{~B} 5=43 ;$ largura $-\mathrm{c} . \quad(\mathrm{BI}$ / B4) 125; o. 15 (média); altura -1. 76; centro d. 26; o. 31/36; a. 69; diâmetro - d. 45; b. 36; orifício bico: $\mathrm{BI}=\mathbf{8}, \mathrm{B} 2=\mathbf{8}, \mathrm{B} 3=\mathbf{8}, \mathrm{B} 4=7$, $\mathrm{B} 5=\mathbf{8}$; orifício d. 7 ; orifício asa: 9 ; espessura - a.: variável; posição da asa: centrada (possivelmente).

Motivos decorativos - Júpiter Capitolino, na asa.

Marca de oleiro - em planta pedis, CTP (?).

Cronologia - segunda metade do séc. I d.C.

\section{N. ${ }^{\circ} 12\left(\mathbf{N}^{\circ}\right.$ Inv. 1233)}

Lucerna - Deneauve VII C. Asa - Ponsich 7.

Pasta - homogénea, compacta, moderadamente dura, não porosa, de cor bege, Munsell 7.5 YR 7/4 (reddish yellow), com e.n.p. de dimensões muito reduzidas (micas e calcites).

Conimbriga, 40 (2001) 237-280 
Engobe - conserva o engobe em mais de 60\%, moderadamente espesso e brilhante, matizado na gama dos castanhos avermelhados, Munsell 2.5 YR 5/8 (red), 2.5 YR 4/8 (dark red), e cinzento, Munsell 10 YR 4/1 (dark gray).

Medidas - comprimento - t. 127; d. 73; bico 26; largura - c. 93; o. 8; altura -1. 48; centro d. 22; o. 30; a. 45; diámetro - d. 74 ; b. 55; orificio bico 8; orificio d. 9; orificio asa 11; espessura - a. 7; posição da asa: centrada.

Motivos decorativos - symplegma erótico. Marca de oleiro NNAELVCI.

Cronologia - tardo-flaviana (quarto quartel do séc. I d.C.) - Adriano.

\section{N. ${ }^{\circ} 13$ (N. ${ }^{\circ}$ Inv. 1234)}

Lucerna - Tipo Dressel-Lamboglia 5 C; Ponsich V C; Loeschcke X (lucerna de canal ou Firmalampe).

Pasta - de boa qualidade, compacta, muito dura, não porosa, com e.n.p. muito pouco visíveis, de cor cinzento esbranquiçado, Munsell 5 Y 7/1 (light gray).

Engobe - Apenas $80 \%$. Aderente, de boa qualidade, escamado, possivelmente brilhante, espesso, de cor preto matizado, Munsell 7.5 YR 3/1 (very dark gray).

Medidas - comprimento - t. 114; d. 50; bico 20; largura - c. 78; o. 13 ; altura - t. 39 ; centro d. 26; o. 35 ; diâmetro - d. 46,5; b. 50,5; orificio bico 11; orificio d. 9 .

Motivos decorativos - cabeça barbada (jovem).

Marca de oleiro - LITOGENE

Cronologia - Flávios (70 d.C.) ao séc. II d.C.

\section{N..$^{\circ} 14\left(\mathrm{~N}^{\circ}\right.$ Inv. 1235)}

\section{Asa - Ponsich 3}

Pasta - homogénea, de textura granulosa, dura e ligeiramente porosa, com escassos e.n.p. (pouco visíveis), de cor bege claro, Munsell 10 YR 8/2 (very pale brown).

Engobe - espesso, brilhante e bastante erodido, de cor matizada na gama dos castanhos acinzentados, Munsell 2.5 Y $6 / 2$ (light brownish gray) e Munsell 7.5 YR 3/1 (very dark gray).

Medidas - comprimento - t. 80; abertura interna crescente: 29; diâmetro - orifício asa: 14 .

Cronologia - séc. I d.C. - 120 d.C. 


\section{N. ${ }^{\circ} 15(\mathrm{AP} / 75)$}

Fragmento de base de lucerna.

Possivelmente do tipo Dressel-Lamboglia 27; Loeschcke VIII (tardia); Ponsich III C, se atendernos ao facto de o oleiro abaixo indicado ter produzido estas formas.

Pasta - compacta, homogénea, branda, muito porosa, com e.n.p. de dimensões muito reduzidas (micas, calcites e pontos negros), de cor beige, Munsell 10 YR 7/6 (yellow).

Engobe - vestigios junto à canelura e em outros locais do fragmento, pouco espesso, possivelmente brilhante, de cor alaranjado, Munsell 5 YR 5/8 (yellowish red).

Medidas - espessura - $3 / 4$.

Marca de oleiro - ERAC

Cronologia - época tardo antonina - Severos (terceiro quartel do séc. II d.C. a 235).

\section{BIBLIOGRAFIA}

abascal Palazón, Juan M. - Apêndice II - Lucernas romanas de Segóbriga. In Segóbriga, /I/, - La muralla norte y la puerta principal - Campañas 1986 - 1987. Cuenca, 1989. p. 299-341.

Alarcão, Adília; Ponte, Salette - Les Lampes. In Étienne, R.; Alarcão, J. - Fouilles de Conimbriga, VI - Ceramiques diverses et verres. Paris, 1976. p. 93-120, Pl. XXIII - XXXI.

AlARCÃo, Jorge - Roman Portugal. Vol. II. Fase. 2. Coimbra Lisboa. Warminster: Aris Phillips, 1988.

- O domínio romano em Portugal. Lisboa, 1988.

- A paisagem rural romana e alto-medieval em Portugal. Conimbriga . Coimbra 37 (1998) 89-119.

ALmeida, José A. F. - Introdução ao estudo das lucernas romanas em Portugal. Lisboa: Universidade de Lisboa, 1952. Tese de doutoramento em Ciências Históricas.

AmANTE SÁNCHEZ, Manuel - Lucernas romanas de la región de Murcia - Hispania Citerior. Murcia, 1993. ISBN 84-7684-395-X.

Amaré, Maria T. - Lucernas romanas de la colección de Don Juan Cabré Aguilo. In Juan Cabré Agidlo (1882 - 1982). Encuentro de Homenaje. Zaragoza, 1985.

— Lucernas en terra sigillata hispánica: XVIII Congresso Nacional de Arqueologia. Islas Canárias. 1985. Zaragoza, 1987.

— Lucernas romanas de La Rioja. Logroño, 1987.

- Lucernas romanas en Aragon. Zaragoza, 1988, ISBN 84-00-66777-9.

— Les llánties. In ALMOGUERA, Arturo - Els materials del Jaciment romá de Raimat, Lleida. Lleida. ISBN 84-00-06830-0 (1988) 145-154.

Conimbriga, 40 (2001) 237-280 
Amaré, Maria T. (et al.) - Avance al estudio de un possible alfar romano en Tarazona: I - Las lucernas. Turiaso. Tarazona. ISBN 0211-7207.IV (1983) 93-110.

Amaré, María T.; García Marcos, Victorino - Una producción de lucernas en Asturica Augusta. Zephyrus. Salamanca. XLVII (1994) 273-285.

Anselmino. L.; Pavolinı, C. - Terra sigillata: lucerne. In Atlante de lie forme ceramiche. I - Cerámica fine romana nel hacino mediterraneo (medio e tardo impero). Roma, 1981. p. 184-207.

ARXé i GÁLVEZ, Joaquim - Les llánties tardo-republicanes d'Empúries. Barcelona, 1982. ISBN 84-500-8534-9.

BAILeY, D. - A catalogue of the lamps in the British Museum, 2. Roman lamps made in Italy. Londres, 1980.

- A catalogue of the lamps in the British Museum, III. Roman provincial lamps. Londres, 1988 ISBN 0-7141-1278-X.

BALIL, A. - Marcas de ceramista en lucernas romanas halladas en España. Archivo Español de Arqueologia. Madrid, vol. 41, n. ${ }^{\circ} 118$ (1968) 158-178.

- Estúdios sobre lucernas romanas I. Studia Archaeologica 2. Santiago de Compostela, 1969.

Becatti, G. - I Mitrei. In Becattı, G. - Scavi di Ostia ///, Volume Secondo. Roma, 1954. Tav. V, XXXIII, XXXIV, XXXV.

BeLCHIOR, Claudette - Lucernas romanas de Conimbriga. Coimbra, 1969.

Belo, A. R. - Nótulas sobre Arqueologia de Torres Vedras e seu termo. VII - Numismática. Badaladas (01 Mai. 1952).

- Nótulas sobre a arqueologia de Torres Vedras e seu termo. XIV - Época Romana. Badaladas (15Ago.1952).

- Nótulas sobre a arqueologia de Torres Vedras e seu termo. XXX - Numismática. Badaladas (01 Ago. 1953).

— Nótulas sobre a arqueologia de Torres Vedras e seu termo. XXXII - A) Numismática. Badaladas (OlOut.1953).

- Nótulas sobre a arqueologia de Torres Vedras e seu termo. XXXV Numismática. Badaladas (01 Jan.1954).

- Nótula sobre quatro lucernas romanas de barro inéditas. Estremadura - Boletim da Junta de Província, II Série. Lisboa. n. ${ }^{\circ}$ L L / LI / LII (1959) 97- 112.

Belo, A. R.; Trindade, L.; Ferreira, O. V. - Lucerna polimyxos do Museu de Torres Vedras. Revista de Guimarães. Guimarães. Vol. LXXIII, nº 1-2 (1963) 315-317.

Beltrán, Miguel - Guía de la cerámica romana. Zaragoza: Pórtico,1990. ISBN 8485264-80-5.

Bergman, Marianne - Die Strahlen der Herrscher: theomorphes Herrscherbild und politische Symbolik im Hellenismus und in der romischen Kaiserzeit.

Mainz, 1998. ISBN 3-8053-1916-9.

BernhARD, Maria L. - Lampki Starozytne. Varsóvia, 1955.

BYRne, Inés N. S. - A rede viária da zona Oeste do Município Olisiponense (Mafra e Sintra). Al-madan. Almada. ISSN 0871-066X. II. Série, Nº. 2 (1993) 41-47.

Cabral, M. E. - Cinco lucernas inéditas da Barrosinha (Alcácer do Sal): ACTAS DAS II JORNADAS ARQUEOLÓGICAS. Lisboa, 1974, vol. II, p. 7-13, Est. I, II.

Conimbriga, 40 (2001) 237-280 
— Lucernas romanas de Alcácer do Sal. O Arqueólogo Português. Lisboa. Série III, VII - IX (1974-77) 347-353.

Caetano, J. C. - A iluminação no Portugal romano. In MEDINA, J. - História de Portugal, dos tempos pré-históricos aos nossos dias. II - O mundo luso-romano. Amadora, 1994, p. 346-350.

CAsas i Genover, L; Rocas i Gutiérrez, X. - Les llànties de la villa romana deis Tolegassos. Algunas précisions entorn la seva datació. Cypsela. Gerona. VII (1989) 71-86.

C.I.L. II - Vascula Varia - Voluminis Secundi Supplementum - Hispaniae Latinae Inscriptionum Supplementum.

C.I.L. XI - Instrumentum Domesticum - Lucernae.

C.I.L. XV - Lucernae - Tituli Notabiliores - Figulorum Nomina.

Clariana i Roıg, J. F. - Les llànties de la villa romana de Torre Llauder (Mataró). Mataró. (1976)41-84.

Costa, Maria E. F. - Lucernas romanas de Tróia de Setúbal. Lisboa: Faculdade de Letras de Lisboa, 1973. Tese de licenciatura em História (policopiada).

CRAWFORD, Michael - Roman Republican coinage. Cambridge, 1974.

Cumont, Franz - Mithra. In SAglio, E. - Dictionnaire des Antiquités Grecques et Romaines. Paris, (s. data). Tome Quatrième, Première Partie, p. 1944-1954.

- Sol. In SAGLIO, E. - Dictionnaire des Antiquités Grecques et Romaines. Paris, (s. data). Tome Quatrième, Deuxième Partie, p. 1373-1386.

De" Spagnolis Conticello, M.; Carolis, Ernesto - Le lucerne di bronzo dei Museo Civico Archeologico di Bologna. Bologna, 1997.

Delgado, Manuela - Un cas de sigillée tardive régional. In Étienne, R.: Alarcão, J.

- Fouilles de Conimbriga, IV. Coimbra, 1975.

Deneauve, Jean - Lampes de Carthage. Paris: CNRS. 1974.

Dıogo, A. M. D. - Cerâmica romana de Alcácer, I. Lisboa, 1980.

- O material romano da primeira campanha de escavações na Alcáçova de Santarém (1979). Conimbriga. Coimbra. 23 (1984) 111-142.

Duarte, A. L.; Raposo, J. C. - Elementos para a caracterização das produções anfóricas da Quinta do Rouxinol (Corroios / Seixal) - OCUPAÇÃO ROMANA DOS ESTUÁRIOS DO TEJO E DO SADO: Actas. Seixal, 1996. ISBN 972-201260-6.p.237-248.

Durrbach, F. - Hercule à Rome. In SAGLIO, E. - Dictionnaire des Antiquités Grecques et Romaines. Paris. 1900. Tome Troisième, Première Partie, p. 124-128.

Ferreira, O. da Veiga; Tavares, J. C. - Objectos luso romanos da Serra de Sintra. Revista de Guimarães. Guimarães. Vol. LXIV (1953) 3-10, Est. I - III.

Fuchs, Werner - DER SCHIFFSFUND VON MAHDIA .Tubingen 1963. Tafel $42,43,44$.

Garcia y Bellido, A.-EI Culto a Sarapis en la Peninsula Ibérica. Boletín de la Real Academia de la Historia. Madrid. Vol. CXXXIX (1956) 293-355.

GIL FARRÉs, O. - Lucernas romanas dei Museo Emeritense. Ampurias. Barcelona. IXX (1947-1948) 97-115. 
- Interesante lucerna inedita del Museo de Mérida. Archivo Español de Arqueologia. Madrid.Tomo XXII (1949) 213-216.

Hanoune, Roger - Lampes de Graviscae. Melanges d'Archéologie et d'Histoire. Paris (1970) 237-262.

HARDEN, D. - The Wint Hill hunting bowl and related glasses. Journal of Glass Studies. Croningen (1960). Vol. II. p. 44-81.

HARLAN, Michael - Roman Republican moneyers and their coins. 63 B.C. - 49 B.C.

London: Seaby, 1995. ISBN 18526476729.

Hermet, F. - La Graufesenque (Condatomago). Paris, 1934.

Hubinger, Ulrich - Die Antiken Lampen. Berlin, 1993.

Hoffmann, Gerd; Schulz, Horst - Cambio de situación de la línea costera y estratigrafía del holoceno en el valle del río Sizandro / Portugal - ACTAS DAS I JORNADAS ARQUEOLÓGICAS DE TORRES VEDRAS. Lisboa: IPPAR. 1995. ISSN 0871-2581. p. 45-46.

IBARRA, A. - Illici, su situation y antigüedades. Alicante, 1879, vasijas IV.

IVANISECVIC, V.; Nikolic-Dordevic, S. - Novi tragovi antickih fortefikaceja u Singidunum - lokalitet knez Mihailava 30. Singidunum. Belgrado. 1 (1997) 65 - 150.

Knowles, Kathryn - The lamps. In Fullford, M.; Peacock, D. P. - Excavations at Carthage - The circular harbour, North Side. The pottery, Vol. //, 2. Oxford, 1994. ISBN 0-19-727004.

LeitÃo, M.; Ponte, S. - Lucernas romanas do Museu Francisco Tavares Proença Júnior (Castelo Branco). Conimbriga. Coimbra. 19 (1980) 151-158.

LoEschCKe, Siegfried - Lampen aus Vindonissa. Zurich, 1919.

LoPes, Maria C. - Cerâmica romana do Museu Municipal de Moura - 4. Lucernas. In Moura na época romana. Moura, 1990.

MACIeL, Manuel J. P. - Arte romana tardia e paleocristã em Portugal. Lisboa: Universidade Nova de Lisboa, 1993. Dissertação de Doutoramento em História da Arte da Antiguidade. 20. Vol. (policopiado).

MAIA, Maria; MAIA, Manuel - Lucernas de Santa Bárbara. Castro Verde, 1997. ISBN 972-97588-0-8.

Mantas, V. G. - Inscrições romanas do Museu Municipal de Torres Vedras. Conimbriga. Coimbra. 21 (1982) 5-99.

- Três inscrições romanas do concelho de Torres Vedras. Conimbriga. Coimbra. 24(1985) 125-149.

- Comércio marítimo e sociedade nos portos romanos do Tejo e do Sado OCUPAÇÃO ROMANA DOS ESTUÁRIOS DO TEJO E DO SADO. Actas. Seixal, 1996. ISBN 972-20-1260-6. p.343-370, fig. 12, 13.

- A rede viária romana da faixa atlântica entre Lisboa e Braga. Coimbra: Faculdade de Letras de Coimbra, 1996. Tese de Doutoramento em História (policopiada).

Martinez, M. - La necrópolis de Hornillo del Camino. Memórias de los Museos Arqueológicos Provinciales. Madrid. Vol. VI (1945) 28, 29, lamina V.5 - 9.

MAYet, F. - Les Céramiques à Parois Fines dans La Péninsule Ibérique. Paris: E. de Boccard. 1975.

Conimbriga, 40 (2001) 237-280 
Les céramiques sigillées hispaniques, II. Paris, 1984.

Mayet, F.; Silva, C. T. - L'atelier d'amphores de Pinheiro (Portugal). Paris: E. de Boccard. 1998.

Menzel, Heinz - Antike Lampen im Römisch - Germanischen Zentralemuseum zu Mainz. Mainz. 1954.

Morillo Cerdan, Angel - Ceràmica romana de Herrera de Pisuerga (Palencia Espana). Las lucernas. Santiago do Chile, 1992. ISBN. 956-7137-04-8.

— Los Astures y Roma; Lucernas. Astur es. Gijón, 1995, p.109 e 285.

Nolen, J. U. S. - Cerâmica comum de necrópoles do Alto Alentejo. Lisboa: Fundação da Casa de Bragança, 1985. p. 151, 152.

- Cerâmicas e vidros de Torre de Ares - Balsa. Lisboa: IPM, 1994. ISBN 972-8137-15-X.

Nolen, J. et all. - Vasos em ceràmica, in Alves, Francisco - Um gosto privado um olhar público - Doações. Lisboa. ISBN 972-8137-11-9 (1995) 77 - 84.

Nunes, J. C.; Guerra, A.; FABIÃo, C. - As lucernas do acampamento militar romano da Lomba do Canho - Arganil. Conimbriga. Coimbra. 29 (1990) 69-90.

OLeiro, J. M. B. - Catálogo de lucernas romanas. Coimbra, 1952.

Palol, P.; Cortes, J. - La villa romana de la Olmeda, Pedrosa de la Vega (Palência). Excavaciones de 1969 y 1970. Acta Arqueológica Hispânica. Madrid. 7 (1974) 152.

Paz Peralta, Juan A. - Ceràmica de mesa romana de los siglos III al VI d.C. en la província de Zaragoza. Zaragoza, 1991. ISBN 84-7820-081-9.

Perdrizet, P. - Le Jupiter italique. In Saglio, E. - Dictionnaire des Antiquités Grecques et Romaines. Paris. 1900. Tome Troisième, Première Partie, p. 708-713.

Perlzweigt, Judith - Lamps of the roman Period. First to seventh century after Christ. The Athenian Agora, volume VII. New Jersey, 1961.

Pinto, Maria J. - Necrópole faz SOS em Torres Vedras. Diário de Notícias (31 Mar. 1995).

PITA, Luís - Um conjunto de lucernas da "Casa do Procurador" (Aljustrel). Vipasca. Aljustrel. ISBN 972-95978-0-4. N. 4 (1995) 15-31.

Ponsich, Michel - Les lampes romaines en terre cuite de la Maurétanie Tingitane. Rabat, 1961.

— Recherches archéologiques à Tanger et dans sa région. Paris, 1970.

- Lixus le quartier des temples. Rabat, 1981.

Ramos Folques, A.; Ramos Fernandez, R. - Excavaciones en la Alcudia de Elche durante los anos (1968-1973). Excavaciones Arqueológicas en Espana. Madrid. 91 (1976).

Ribeiro, Fernando N. - Lucernas romanas de Peroguarda (Ferreira do Alentejo). Arquivo de Beja. Beja. Voi. XVI (1960).

Ribeiro, J. Cardim - Estudos histórico-epigráficos em torno da figura de L. Ivlivs Maelo Cavdicvs. Sintria. Sintra. I - II (1982-1983) 151-476.

- FELICITAS IVLIA OLISIPO - Algumas considerações em torno do catálogo Lisboa Subterrânea. Al-madan. Almada. II Série, nº 3 (1994) 76-78.

Rıccı, Marina - Per una cronologia delle lucerne tardo-republicane. Rivista di Studi Liguri. Bordighera. XXXIX, 2-4 (1973) 168-234.

Conimbriga, 40 (2001) 237-280 
Rodríguez Martin, F. G. - Materiales de un alfar emeritense. Paredes finas, lucernas, sigillatas y terracotas. Cuadernos Emeritenses 11. Mérida: Museo Nacional de Arte Romano, 1996.

Ruivo, José da Silva - Inventário sumário da colecção de numismática romana do Museu Municipal de Torres Vedras. Torres Vedras, s/d (policopiada).

- Circulação monetária na Estremadura portuguesa até aos inícios do século III. Porto: Faculdade de Letras da Universidade do Porto, 1995. Dissertação de Mestrado em Arqueologia (policopiada), p. 49-55.

SEAR, David - Roman coins and their values. Londres: Seaby, 1981.

SepúlvedA, Eurico - Terra Sigillata Tardo-Itálica ( Padana) proveniente de Tróia de Setúbal. Al-madan. Almada. N. ${ }^{\circ}$ 5, II Série. ( 1996 ) 13-17.

Silva, Carlos T.; SoAres, Antonia C. - A Praça do Bocage (Setúbal) na época romana. Escavações arqueológicas de 1980. Setúbal Arqueológica. Setúbal: Assembleia Distrital de Setúbal. VI - VII (1980-81) 268.

Sousa, E. M.; Sepúlveda, E. - Materiais inéditos da necrópole romana da Herdade da Barrosinha (Alcácer do Sal) - A colecção dos Comendadores Nunes Ribeiro. Conimbriga. Coimbra. 36 (1997) 103-122.

SousA, J. J. R. - Acerca de um molde de lucernas. Trabalhos de Antropologia $e$ Etnologia. Porto. XX (1965-66) 165-172.

- Novo molde de lucernas aparecido em Braga. Trabalhos de Antropologia e Etnologia. Porto. XXI (1969) 309-311.

Squarzant, Stefania et al. - 7. Lucerne. In MARINI, G. - Archeologia Urbana a Eiesole - Lo scavo di Via Marini - Via Portegiani. Firenze, 1990. ISBN 88-0920117-9.

Starac, Alka - Rimske svjetiljke iz nekropole na Morsovom Polju u Poli. Histria Archaeologica. Pula. 22-23 / 1991-1992 (1993) 4-43.

TeixeIRA, António; SILVA, Rodrigo B. - Molde de lucerna do Sítio do Nicolau. Arquivo de Beja. Beja. Vol. VIII, 2a . Série (1986) 147-152.

ToRRes. Manuel M. - Descripção Histórica e Económica da Villa e Termo de Torres Vedras.

Memórias da Academia Real das Ciências de Lisboa. Coimbra. Tomo VI parte primeira. Edição especial 1861.

Trindade, L.; Ferreira, O. V. - Objectos inéditos lusitano-romanos no Museu de Torres Vedras. Boletim Cultural da Junta Distrital de Lisboa. Lisboa. n . 61/62 (1964) 265-278.

Valenzani, Ricardo S. - Suppelletile da illuminazione (Lucerna). In Carandini, A. Settefinestre, una villa schiavistica nelTEtruria romana. 2. La villa e $i$ suoi reperti. Roma, 1986, p. 212-215.

Vasconcellos, J. L. - 23. Candelabro de Pavia. O Archeologo Português. Lisboa. Vol. XXVI (1924) 35,36.

Vegas, M. - Motivos decorativos en lucernas de disco romanas sus antecedentes e paralelos. Pyrenae. Barcelona. 2 (1966) 81-93, laminas I - VIII.

VıanA, Abel - Alcácer do Sal. Arquivo de Beja. Beja, Vol. V (1948) 9, 10, fig. 11, 12.

Conimbriga, 40 (2001) 237-280 
- Lucernas de Peroguarda. In Notas Históricas, Arqueológicas e Etnográficas do Baixo Alentejo. Beja: 1957. p. 16-31.

- Algumas noções elementares de Arqueologia prática. Beja, 1962. p. 114, 115; fig. 131, 132.

Viana, A.; Deus, A. D. - Necropolis de la Torre das Arcas. Archivo Español de Arqueologia. Madrid. XXVIII, (1955) 244-265.

Catálogos consultados

Portugal Das Origens à Época Romana ; Lista de peças em exposição. - Museu Nacional de Arqueologia e Etnologia. IPPC. S/d.

Antiquarium Comunale - A cura di Sommella, Anna ; Salvetti, Carla. Roma (1994) 35, fig. 40. ISBN 88-7621-154-3.

Museu de Mértola ; Basílica Paleocristã - Coordenação de Torres, Cláudio ; Macias, Santiago. Mértola (1993). ISBN 972-9375-02-X. 

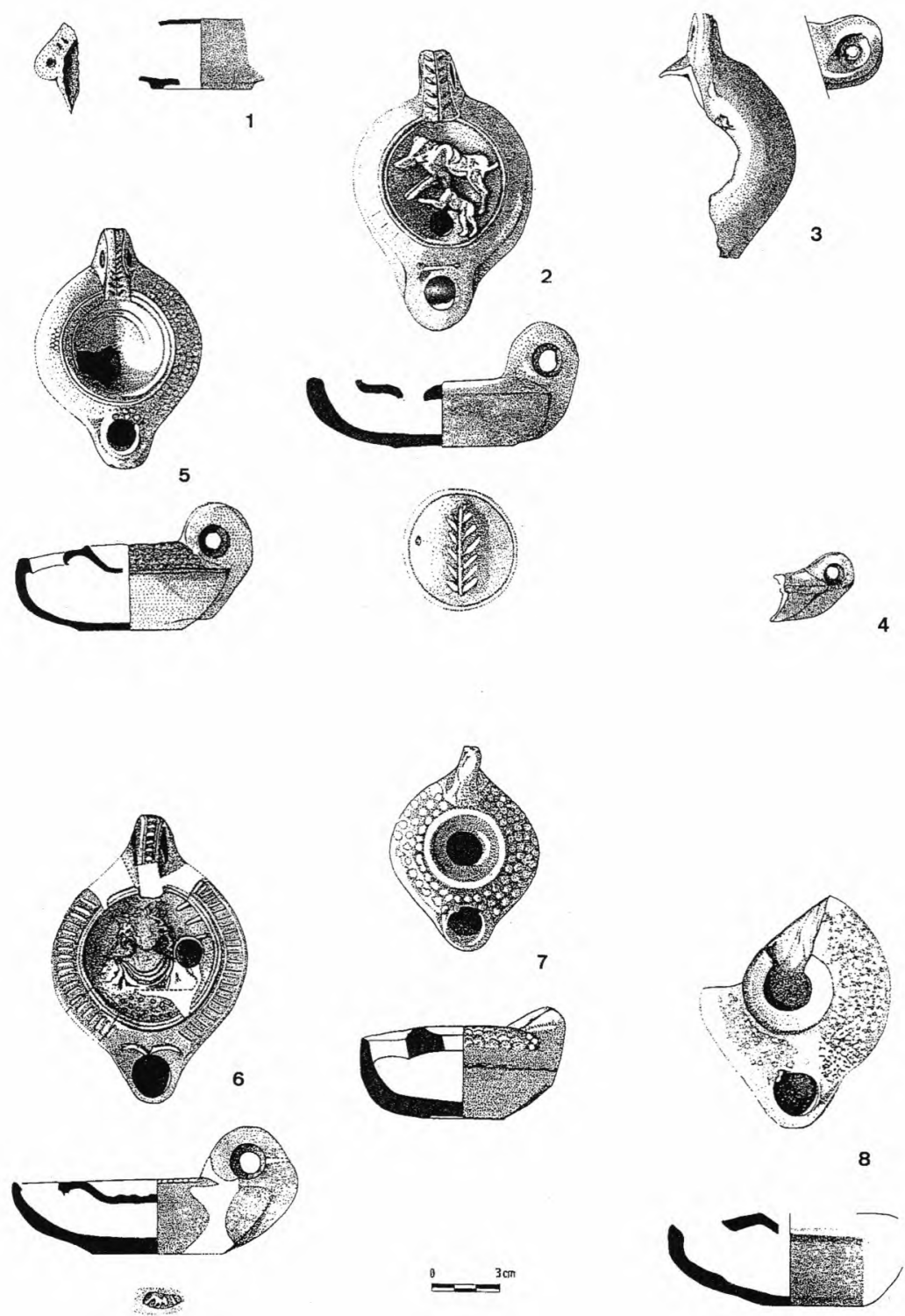

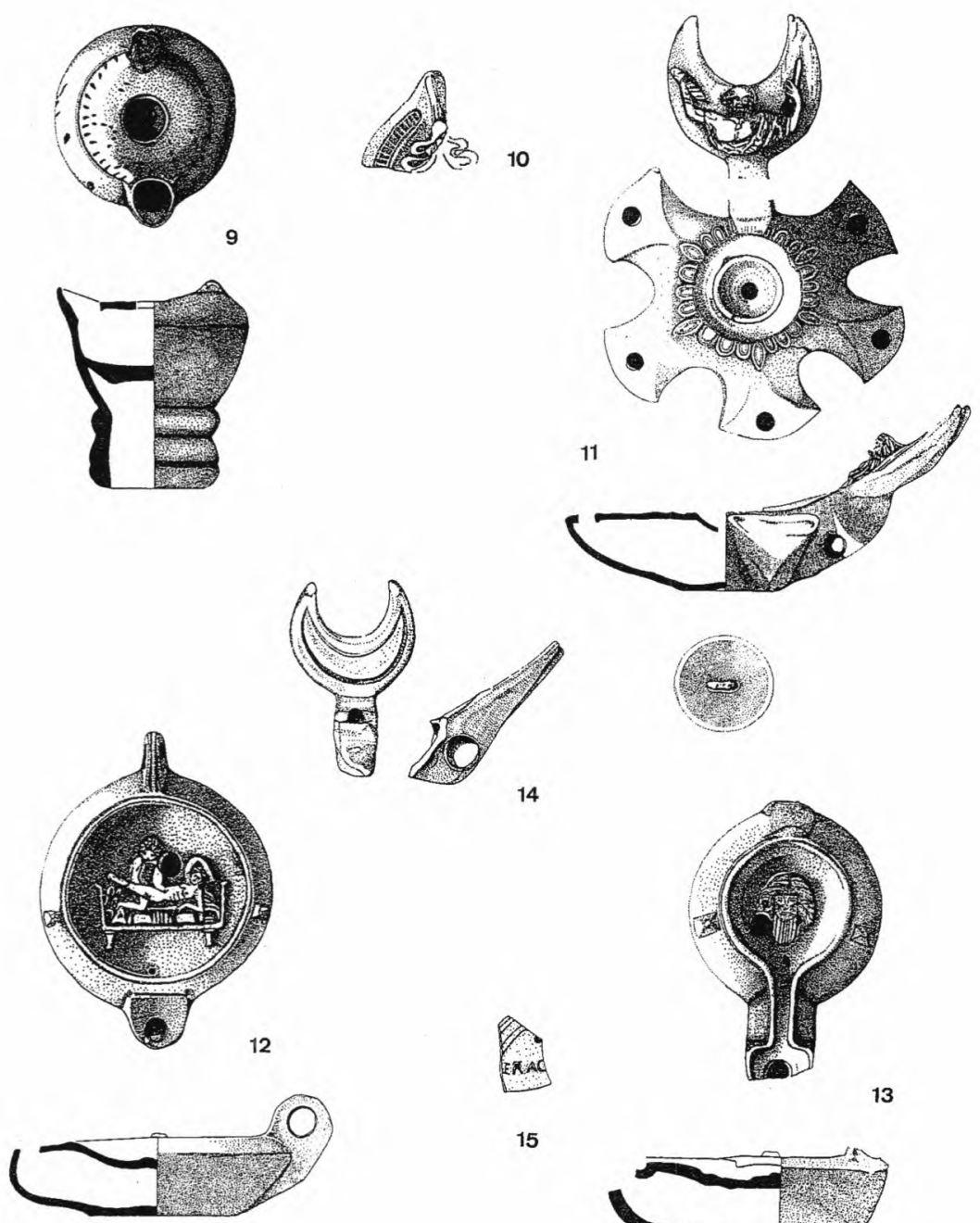

15
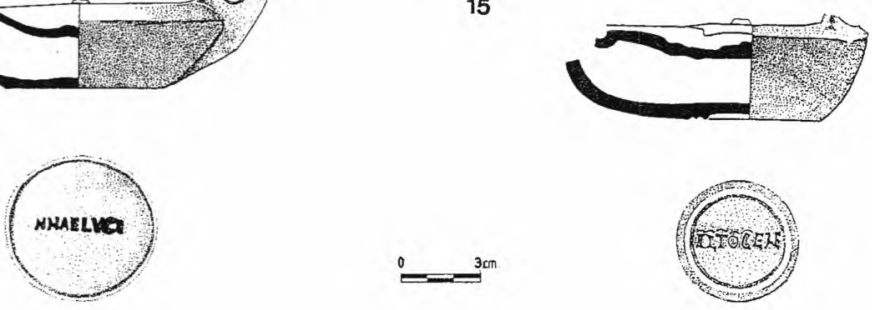